\title{
Assessing hydromorphological and floristic patterns along a regulated Mediterranean river: The Serpis River (Spain)
}

\author{
Virginia Garófano-Gómez ${ }^{1, *}$, Francisco Martínez-Capel ${ }^{1}$, Matías Peredo-Parada ${ }^{2}$, Esther Julia \\ Olaya Marín ${ }^{1}$, Rafael Muñoz Mas ${ }^{1}$, Rui M. Soares Costa ${ }^{1}$ and Jose Luis Pinar-Arenas ${ }^{3}$ \\ ${ }^{1}$ Institut d'Investigació per a la Gestió Integrada de Zones Costaneres (IGIC). Universitat Politècnica de \\ València. C/ Paranimf 1, 46730 Grau de Gandia. València. España. \\ ${ }^{2}$ Plataforma de Investigación en Ecohidrología y Ecohidráulica. EcoHyd. C/ Almirante Riveros 075. Santiago, \\ Chile. \\ ${ }^{3}$ Argente Mascarós Ingenieros S.L. C/ Ingeniero José Sirera, Puerta 1, Patio 4. 46017 Valencia. España. \\ * Corresponding author: virgargm@upvnet.upv.es
}

Received: 5/4/2010

Accepted: 20/4/2011

\begin{abstract}
Assessing hydromorphological and floristic patterns along a regulated Mediterranean river: The Serpis River (Spain)

In the European context, several methodologies have been developed to assess the ecological status and, specifically, the hydromorphological status of running surface waters. Although these methodologies have been widely used, few studies have focused on hydrologically altered water bodies and the factors that may determine their status. In this study, the Serpis River was divided into 16 segments from the Beniarrés dam (40 km from the river mouth) to the sea, all of which are affected by flow regulation, but with different severity. In each segment, an inventory of the flora was conducted, and hydromorphological indices (QBR, Riparian Habitat Quality Index; and IHF, River Habitat Index) were applied. The objectives of the study were (A) to identify relationships between floristic composition and QBR components and (B) between instream habitat characteristics and IHF components as well as (C) to determine the main factors controlling the floristic composition and riparian habitat quality (QBR) and the factors controlling instream habitat characteristics and heterogeneity (IHF). A cluster analysis allowed grouping sites according to their floristic composition and instream habitat characteristics, and non-metric multidimensional scaling (NMDS) was used to ordinate the sites, obtaining the biotic and instream habitat characteristics, as well as the QBR and IHF subindices, which better explained the spatial patterns. Finally, a canonical correspondence analysis (CCA) with predictor variables (geographical, hydrological, geomorphological and human pressures) indicated the main factors controlling the spatial patterns of the floristic composition, instream habitat characteristics, riparian habitat quality and instream habitat heterogeneity. A gradient of riparian and instream habitat quality was identified. Our results suggest that physical constraints (presence of a gorge) have protected sites from severe human impacts, resulting in good ecological quality, despite hydrological alteration. This area, where there is geomorphological control, could be potentially reclassified into a different ecotype because regular monitoring could be using incorrect references for index scores, and naturally high scores could be confused with recovery from hydrological alteration or other pressures. The sites with the worst quality were near the river mouth and were characterised by an artificial and highly variable flow regime (related to large autumnal floods and frequent human-induced periods of zero flow). This artificial flow variability as well as the presence of lateral structures in the river channel and geomorphological characteristics were identified as the main factors driving the hydromorphological and floristic pattern in this regulated river.
\end{abstract}

Key words: Hydromorphological indices, ecological status, floristic composition, ecotypes, Júcar River Basin, environmental flows, Mediterranean rivers.

\section{RESUMEN}

Evaluación de los patrones hidromorfológicos y florísticos a lo largo de un río mediterráneo regulado; el río Serpis (España)

Diversas metodologías han sido desarrolladas en el contexto europeo para evaluar el estado ecológico, y específicamente el estado hidromorfológico de las aguas superficiales. Aunque éstas han sido ampliamente utilizadas, pocos estudios se han 
centrado en masas de agua hidrológicamente alteradas y en los factores que condicionan su estado. En este estudio, el río Serpis fue dividido en 16 segmentos desde la presa de Beniarrés (a $40 \mathrm{~km}$ de la desembocadura) hasta el mar, todos ellos afectados por la regulación de caudales con distinta severidad. En cada segmento se realizó un inventario florístico y se aplicaron índices hidromorfológicos (QBR, Calidad del Bosque de Ribera, e IHF, Índice de Hábitat Fluvial). Los objetivos del estudio fueron (A) identificar relaciones entre la composición florística y los componentes del QBR, (B) entre las características del hábitat fluvial y los componentes del IHF, $(C)$ determinar los principales factores que controlan la composición florística y la calidad del hábitat ripario (QBR), y las características del hábitat fluvial y su heterogeneidad (IHF). Un cluster permitió agrupar los puntos de muestreo según su composición florística y las características del hábitat fluvial, y un escalado multidimensional no-métrico (NMDS) fue usado para ordenar los puntos, obteniendo las variables bióticas y características del hábitat y los subindices del QBR e IHF, respectivamente, que explicaban mejor los patrones espaciales. Finalmente, un análisis de correspondencias canónicas (CCA) con variables predictoras (geográficas, hidrológicas, geomorfológicas y presiones humanas) indicó los principales factores que controlan los patrones espaciales de la composición florística, las características del hábitat fluvial, la calidad del hábitat ripario y la heterogeneidad del hábitat fluvial. Se identificó un gradiente de calidad del hábitat ripario y fluvial. Los resultados sugieren que las limitaciones físicas (presencia de un cañón) han protegido a los tramos de impactos humanos severos, resultando en una buena calidad ecológica a pesar de la alteración hidrológica. Esta zona podría potencialmente ser reclasificada en un ecotipo diferente, ya que un monitoreo regular podría estar usando referencias incorrectas para los índices y sus altas puntuaciones naturales se podrían estar confundiendo con una recuperación de la alteración hidrológica o de otras presiones. Los puntos de muestreo con peor calidad estuvieron cerca de la desembocadura y tuvieron un régimen de caudales alterado y muy variable. Esta variabilidad artificial del caudal, junto con la presencia de estructuras laterales en el cauce y las características geomorfológicas fueron identificadas como los principales factores determinantes del patrón hidromorfológico y florístico en este río regulado.

Palabras clave: Índices hidromorfológicos, estado ecológico, composición florística, ecotipos, cuenca del Júcar, caudales ecológicos, ríos mediterráneos.

\section{INTRODUCTION}

The flow regimes of Mediterranean streams exhibit strong seasonal and annual variability (Blondel \& Aronson, 1999; Gasith \& Resh, 1999). This variability has been one of the main motivations for the construction of dams in regions with a Mediterranean climate, such as Spain, where there are approximately 1200 large dams (World Commission on Dams, 2000; Kondolf \& Batalla, 2005). These hydraulic structures provide many services to society, e.g., flood control, power generation and supplying water for irrigation, drinking water, industrial use and recreation; however, they also modify basic components of the flow regime. These alterations have produced many hydromorphological and biotic changes in Mediterranean river ecosystems. Moreover, flow regimes are associated with biological and physical thresholds that determine river dynamics, and thus the presence of different flora and fauna communities (Poff et al., 1997). This flow-biota interaction is especially remark- able in Mediterranean rivers (Prenda et al., 2006) due to their high biological diversity and extremely variable flow regimes (Blondel \& Aronson, 1999; Naiman et al., 2008).

Hydraulic structures, such as dams, not only disrupt the longitudinal continuity of the flow within a river, but also act as barriers to sediments, fish migration and vegetation propagules (Brierley \& Fryirs, 2005; Charlton, 2008). In addition, they induce changes in the thermal regime, water quality and biogeochemical fluxes, impacting habitat availability and connectivity along the fluvial continuum (Van Steeter \& Pitlick, 1998; Brierley \& Fryirs, 2005; Garde, 2006). Lateral connectivity is also altered by the reduction of the frequency, magnitude and duration of events that periodically flood banks and floodplains (Charlton, 2008), causing loss of native riparian vegetation (Burch et al., 1987). Many native species of riparian vegetation exhibit life cycles adapted to seasonal peak flows, the loss of which may hinder the regeneration of these riparian communities, reducing their 
growth rates or favouring the invasion of alien species (Poff et al., 1997).

Integrity of the hydrogeomorphological processes in rivers is crucial to ensure the complexity and heterogeneity of fluvial ecosystems (Poff et al., 1997; Brierley \& Fryirs, 2005). For this reason, assessment of hydromorphological characteristics within fluvial ecosystems has been established as a component in evaluating the ecological status of rivers in Europe (i.e., the Water Framework Directive: WFD; European Commission, 2000) and worldwide (e.g., the Clean Water Act in North America; US Government, 1977). The hydromorphological quality elements to be addressed in these evaluations (listed in Annex $\mathrm{V}$ of the WFD) are the hydrological regime (characterised by the quantity and dynamics of water flows and connection to groundwater bodies), river continuity and morphological conditions (characterised by river depth and width variation, the structure and substrate of the riverbed and the structure of the riparian zone). According to these criteria, several researchers have developed methods to monitor the effects of hydromorphological pressures on rivers with respect to floodplain, riparian, bank and channel characteristics (Fernández et al., 2011).

On the Iberian Peninsula, regarding the assessment of riparian characteristics, Munné et al. (1998) proposed the Riparian Habitat Quality Index (QBR, from its original name Qualitat del Bosc de Ribera) to assess the ecological quality of riparian habitats in rivers and streams, while Gutiérrez et al. (2001) developed the River Vegetation Index (IVF, from Índex de Vegetació Fluvial), which integrates floristic information and evaluates the conservation status of riparian zones using riparian vegetation as a bioindicator (ACA, 2008); the latter index requires more detailed knowledge of flora than other indices. Moreover, using a more functional approach, the Riparian Quality Index (RQI) proposed by González del Tánago et al. (2006) considers the structure and dynamics of riparian zones in a hydrological and geomorphological context, in contrast to other methods, which focus almost exclusively on assessing the current state of vegetation cover (González del Tánago et al., 2006).
Magdaleno et al. (2010) proposed the Riparian Forest Evaluation (RFV) to assess the ecological condition of riparian forests in perennial rivers. RFV has also been designed to be calculated with LIDAR data, which represents an advance compared to the aforementioned indices, as it can be calculated for larger areas.

With respect to the assessment of instream channel characteristics, the River Habitat Index (IHF, from its original name Índice de Hábitat Fluvial) evaluates relationships between habitat heterogeneity and physical variables related to the stream channel, which are influenced by hydrology and substrate composition (Pardo et al., 2004). However, it does not assess hydromorphological features themselves but instead evaluates their quality for associated aquatic communities (Ollero et al., 2008). Quite recently, Ollero et al. (2008) created the Index for HydroGeomorphological assessment (IHG, from its original name Índice Hidrogeomorfológico), in which the main focus is on the protection of hydrogeomorphological dynamics, as they are an essential issue for river conservation; this index considers the functional quality of fluvial systems, channel quality and the quality of river banks (Ollero et al., 2009; Ollero et al., 2011).

Although all these indices are currently in use, few studies have focused on their performance in hydrologically altered water bodies. Moreover, the indices' ability to reflect the correspondence between hydrological alteration and hydromorphological status in regulated river systems has not been properly tested. Thus, in the present study, we were interested in investigating the response of riparian flora and certain instream habitat characteristics in an altered river ecosystem as well as of the QBR and IHF indices, which are the most widely used indices by Spanish water administrations (Aguilella et al., 2005; ACA, 2006). Therefore, the objectives of this study were A) to identify relationships between floristic composition and QBR values at sites in a hydromorphologically altered river; B) to identify relationships between instream characteristics and IHF values at the same altered sites; and C) to determine the main factors controlling the floristic composition and riparian habitat quality 
(QBR), instream habitat characteristics and instream habitat heterogeneity (IHF) at these sites.

\section{METHODS}

\section{Study area}

The source of the Serpis River is situated 1462 $\mathrm{m}$ above sea level and is surrounded by two natural parks (Carrascar de la Font Roja and Serra Mariola). Its basin $\left(752.8 \mathrm{~km}^{2}\right)$ is included in two provinces, Alicante (headwaters and middle course) and Valencia (East of Spain), within the domain of the Júcar River Basin District (Fig. 1). The river runs $74.5 \mathrm{~km}$ from SW to NE to reach the Mediterranean Sea. It is intermittent in the initial part of its upper basin, but soon thereafter it exhibits a regular course following the confluence with the Valleseta, Penàguila, Barchell and Polop Streams. The main tributaries in the middle course are the Barranco de l'Encantada and the Agres Stream; and finally, the Bernisa River in the lower course.

The main climate type in the basin is coastal Mediterranean (Pérez, 1994), with an average annual temperature of $16.3{ }^{\circ} \mathrm{C}$ and average annual precipitation of $630 \mathrm{~mm}$ (Viñals et al., 2001). With respect to its lithology and geology, the Serpis river basin rises from the tip of the Betic mountain range at its Mediterranean coastal extreme. The upper basin, near Alcoy (Alicante),

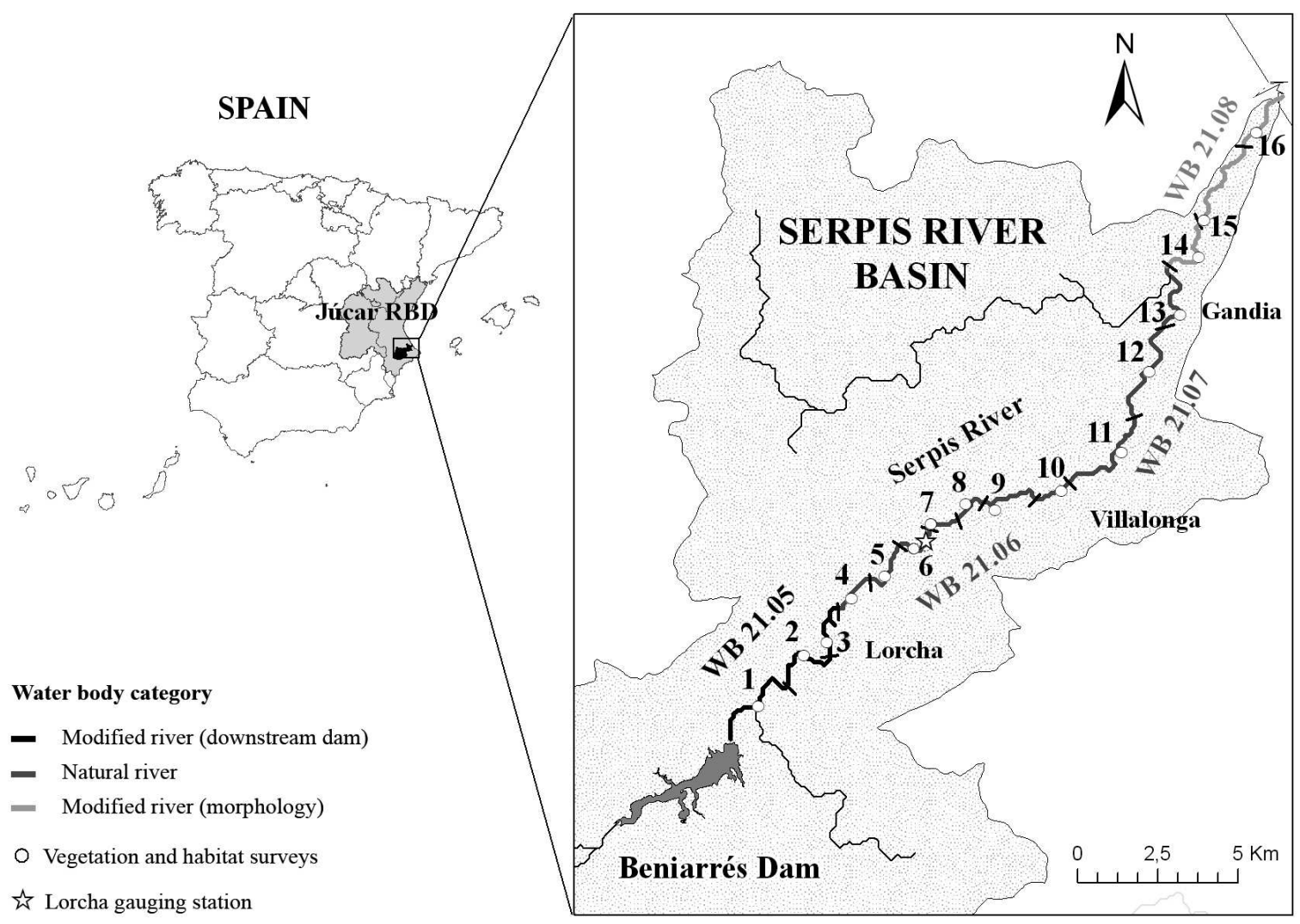

Figure 1. Location of the 16 study sites and segments in the Serpis River downstream of the Beniarrés dam in the Júcar River basin District (RBD), East Spain. Water body categories follow the classification of the Júcar River Basin Authority. Localización de los 16 puntos de muestreo y segmentos en el río Serpis aguas abajo del embalse de Beniarrés en la demarcación hidrográfica del río Júcar (RBD), Este de España. Las categorías de las masas de agua son acordes con la clasificación de la Confederación Hidrográfica del Júcar. 
runs across marl deposits. The only large dam is found in the middle course (Beniarrés), associated with geology consisting of limestone and marls. From Lorcha $(8 \mathrm{~km}$ downstream of the dam), the river becomes narrower as it flows through the limestone gorge known as Barranco del Infierno, which ends near Villalonga. After this town, the valley widens and the floodplain is covered by irrigated farmland, smallholdings and a high proportion of citrus orchards. The mouth of the river is located on alluvial quaternary deposits in the coastal plain known as Plana de Gandia-Denia. Although remarkable morphological differences are observed within the river, its entire course has been classified into one ecological typology: mineralised river in middle and low mountain (ecotype 9; CEDEX, 2004).

The study area consists of the territory from the Beniarrés dam to the river mouth, where four water bodies have been distinguished within this area (Fig. 1) by the Júcar River Basin Authority (CHJ, 2005; 2009). According to the WFD (article 2.10), a water body is a discrete and significant element of surface water, such as a river, lake or reservoir, or a distinct volume of groundwater within an aquifer. Water bodies exhibit homogeneous characteristics in their extension and length and can be separated from other water bodies due to the presence of artificial barriers (e.g., weirs or reservoirs) or natural hydromorphological changes, such as the confluence of two rivers or the presence of protected areas. According to article 2 of the WFD, a water body can be identified as heavily modified (HMWB) by a European Member State (in accordance with the provisions of Annex II) if human activity has substantially changed its nature (hydromorphological characteristics), and it is not possible to achieve a good ecological status. This is the case for the first water body below the dam (code 21.05) because its flow regime is substantially altered by the dam. The second and third water bodies (codes 21.06 and 21.07), which are located in the gorge, have been classified as natural by the water authority, despite presenting an impaired flow regime. Finally, the fourth water body (code 21.08) has also been classified as an HMWB, mainly due to severe changes in its original morphology (almost the whole river course is channelized).

The large Beniarrés dam, located $40 \mathrm{~km}$ upstream of the river mouth, has altered the hydrological regime of the Serpis River to supply irrigation water since its construction in 1958. According to the CHJ (2007), water abstraction from surface water bodies is mainly carried out for the purpose of irrigation because urban areas are supplied from wells. The main irrigation channels in the basin in terms of the volume of water abstracted are Canales Altos del Serpis (located in site 8) and Acequia Real de Gandía (in site 11). These two channels supply $81.2 \%$ of the total demand of surface water, which is considered to represent high abstraction pressure on the river. In addition to these hydrological modifications, the Serpis River is associated with important point and diffuse pollution sources due to certain land uses and fires, respectively, and the most substantial morphological changes in the river are related to structures for water regulation and abstraction as well as the canalisation of its final reach (CHJ, 2005).

\section{Geographical characterisation}

To explore the characteristics of this river, the 4 water bodies were divided into 16 homogeneous segments based on several previous visits to the area and aerial photographs of the catchment. Differences in valley form, riparian vegetation composition, the presence of artificial structures and discontinuities in adjacent land uses were also taken into account in the segmentation process. The first water body immediately downstream of the dam included 3 segments; 10 segments were located in the two following water bodies; and the last 3 segments were situated in the most downstream water body (Table 1). In each segment, a representative study site of $100 \mathrm{~m}$ in length was selected to calculate index scores and to carry out vegetation inventories. For a full description of the sites, see Garófano-Gómez et al. (2009).

Elevation (Elev; in $\mathrm{m}$ above sea level) and distance to the nearest weir upstream (DistWeir; $\mathrm{km}$ ) were determined at the central point of 
Table 1. Environmental characteristics of the 4 water bodies studied in the Serpis River, East Spain (X: mean value, R: range, SD: standard deviation). Variable codes are explained in the text in the methods section. Características ambientales de las 4 masas de agua consideradas en el río Serpis, España (X: valor medio, $R$ : rango, SD: desviación estándar). Los códigos de las variables están explicados en métodos.

\begin{tabular}{|c|c|c|c|c|c|c|c|c|c|c|c|c|}
\hline $\begin{array}{l}\text { WB code* } \\
\text { WB name }\end{array}$ & Ben & $\begin{array}{l}21.05 \\
\text { iarrés Dam-Lor }\end{array}$ & cha & & $\begin{array}{c}21.06 \\
\text { rcha-Reprimal }\end{array}$ & & Rep & $\begin{array}{c}21.07 \\
\text { rimala-La Mu }\end{array}$ & & & $\begin{array}{c}21.08 \\
\text { La Murta-Sea }\end{array}$ & \\
\hline \multirow{3}{*}{$\begin{array}{l}\text { Segments } \\
\text { Total length }(\mathbf{k m})\end{array}$} & & $1,2,3$ & & & $4,5,6,7,8,9$ & & & $10,11,12,13$ & & & $14,15,16$ & \\
\hline & & 8.07 & & & 10.22 & & & 10.43 & & & 8.17 & \\
\hline & $\mathrm{X}$ & $\mathrm{R}$ & $\mathrm{SD}$ & $\mathrm{X}$ & $\mathrm{R}$ & SD & $\mathrm{X}$ & $\mathrm{R}$ & SD & $\mathrm{X}$ & $\mathrm{R}$ & SD \\
\hline Elev (masl) & 257.2 & $(243.0-273.0)$ & 15.1 & 184.3 & $(134.0-229.0)$ & 35.5 & 61.3 & $(32.5-94.5)$ & 27 & 10 & $(3.5-15.0)$ & 5.9 \\
\hline Length (km) & 2.7 & $(1.8-3.6)$ & 0.9 & 1.8 & $(1.3-2.3)$ & 0.4 & 3.1 & $(1.3-4.2)$ & 1.3 & 2.6 & $(2.0-3.2)$ & 0.6 \\
\hline DistRese (km) & 4.6 & $(1.8-6.9)$ & 2.6 & 13.2 & $(9.0-16.9)$ & 2.9 & 24.3 & $(19.7-28.8)$ & 4 & 34.8 & $(32.6-37.8)$ & 2.7 \\
\hline Area $\left(\mathbf{k m}^{2}\right)$ & 33.5 & $(7.7-49.8)$ & 22.5 & 80.5 & (71.9-90.8) & 7.4 & 114.5 & $(97.3-132.9)$ & 15.9 & 304 & $(289.1-331.2)$ & 23.6 \\
\hline SlopeArea (\%) & 25 & $(22.1-26.7)$ & 2.5 & 30.4 & $(28.0-32.5)$ & 1.7 & 32.5 & $(30.3-34.0)$ & 1.7 & 26.6 & $(26.4-26.9)$ & 0.3 \\
\hline SlopeReach (\%) & 0.6 & $(0.5-0.7)$ & 0.1 & 1.3 & $(0.8-2.1)$ & 0.5 & 0.6 & $(0.5-0.7)$ & 0.1 & 0.2 & $(0.2-0.3)$ & 0.1 \\
\hline DistWeir (km) & 4.7 & $(1.9-6.9)$ & 2.5 & 4.3 & $(0.8-10.7)$ & 4.3 & 2.5 & $(1.4-4.9)$ & 1.6 & 10.9 & $(8.7-13.9)$ & 2.7 \\
\hline $\operatorname{Fmin}\left(\mathbf{m}^{3} / \mathbf{s}\right)$ & 0.2 & $(0.2-0.2)$ & 0 & 0.1 & $(0.0-0.2)$ & 0.1 & 0 & $(0.0-0.0)$ & 0 & 0 & $(0.0-0.0)$ & 0 \\
\hline Fmean $\left(\mathrm{m}^{3} / \mathbf{s}\right)$ & 1.1 & $(1.1-1.1)$ & 0 & 1 & $(0.7-1.1)$ & 0.1 & 0.7 & $(0.6-0.7)$ & 0.1 & 0.9 & $(0.9-1.0)$ & 0 \\
\hline $\operatorname{Fmax}\left(\mathbf{m}^{3} / \mathbf{s}\right)$ & 14.5 & $(14.5-14.5)$ & 0 & 14.5 & $(14.5-14.7)$ & 0.1 & 15.5 & $(14.7-16.3)$ & 0.7 & 22.6 & $(22.5-22.9)$ & 0.2 \\
\hline Fper10 & 0.4 & $(0.4-0.4)$ & 0 & 0.3 & $(0.0-0.4)$ & 0.2 & 0 & $(0.0-0.1)$ & 0 & 0 & $(0.0-0.0)$ & 0 \\
\hline Fper95 & 2.1 & $(2.1-2.1)$ & 0 & 2.1 & $(2.0-2.1)$ & 0 & 2.1 & $(2.0-2.2)$ & 0.1 & 2.9 & $(2.9-3.0)$ & 0 \\
\hline Fsd & 1.5 & $(1.5-1.5)$ & 0 & 1.5 & $(1.5-1.5)$ & 0 & 1.6 & $(1.5-1.7)$ & 0.1 & 2.4 & $(2.4-2.4)$ & 0 \\
\hline Fev & 1.4 & $(1.4-1.4)$ & 0 & 1.5 & $(1.4-2.1)$ & 0.3 & 2.5 & $(2.1-2.8)$ & 0.4 & 2.5 & $(2.5-2.5)$ & 0 \\
\hline
\end{tabular}

* According to Júcar River Basin Authority.

each site. Segment length (Length; km), distance from the Beniarrés dam (DistRese; $\mathrm{km}$ ), mean slope (SlopeReach; \%), accumulated watershed area (Area; $\mathrm{km}^{2}$ ) below the dam (upstream of the dam discounted) and watershed mean gradient (SlopeArea; \%) were determined for each river segment. These characteristics were calculated from 1:10 000 scale maps using Archydro extensions created by the Center for Research in Water Resources (University of Texas-Austin, 2003) for ArcGIS ${ }^{\mathrm{TM}}$ 9.3.1 software of ESRI (Redlands, California, 2009).

\section{Biological data collection}

A rectangular plot of $400 \mathrm{~m}^{2}$ was the sampling area for conducting flora inventories at each site. Inventories were carried out during the dry season (August 2006). Plant species were recorded and the overhead percentage cover was estimated visually using the modified Braun-Blanquet coverabundance scale (Mueller-Dombois \& Ellenberg, 1974) as follows: + (a few scattered specimens, canopy cover < 1\%), 1 (1-10 \%), 2 (11-25\%), 3
$(26-50 \%), 4(51-75 \%), 5(76-100 \%)$. Species not identified in the field were collected and identified in an herbarium. To analyse the floristic data, the ranks were transformed to the mean percentage cover of each class $(1,5,17.5$, $37.5,62.5$ and 87.5), which is a common transformation of cover to abundance in phytosociology (van der Maarel, 1979; Wildi, 2010).

Seventeen variables were obtained from the floristic data (Table 2): total richness (Richness), richness of annual herbs (AnnualH), perennial herbs (PerennH), shrubs (Shrubs), trees (Trees), ferns (Ferns) and hydrophytes (Hydroph), richness of native (Natives) and exotic species (Exotics) and the abundance percentages of the aforementioned groups(P.AnnualH, P.PerennH, P.Shrubs, P.Trees, P.Ferns, P.Hydroph, P.Natives, P.Exotics).

\section{Hydromorphological characterisation}

The medians of the mean daily flows by months were calculated for two time periods: (a) 19431953, i.e., the natural flows before dam construction; and (b) 1999-2009, i.e., the regulated 
Table 2. Biotic characteristics of the 4 water bodies studied in the Serpis River, East Spain (X: mean value, R: range, SD: standard deviation). Variable codes are explained in the text in the methods section. Características bióticas de las 4 masas de agua consideradas en el río Serpis, España (X: valor medio, $R$ : rango, SD: desviación estándar). Los códigos de las variables están explicados en métodos.

\begin{tabular}{|c|c|c|c|c|c|c|c|c|c|c|c|c|}
\hline $\begin{array}{l}\text { WB code* } \\
\text { WB name }\end{array}$ & & $\begin{array}{c}21.05 \\
\text { niarrés Dam- }\end{array}$ & cha & & $\begin{array}{c}21.06 \\
\text { rcha-Reprim }\end{array}$ & & & $\begin{array}{c}21.07 \\
\text { primala-La } I\end{array}$ & & & $\begin{array}{c}21.08 \\
\text { a Murta-Sea }\end{array}$ & \\
\hline \multirow[t]{2}{*}{ Segments } & \multicolumn{3}{|c|}{$1,2,3$} & \multicolumn{3}{|c|}{$4,5,6,7,8,9$} & \multicolumn{3}{|c|}{$10,11,12,13$} & \multicolumn{3}{|c|}{$14,15,16$} \\
\hline & $X$ & $\mathrm{R}$ & $\mathrm{SD}$ & $X$ & $\mathrm{R}$ & SD & $X$ & $\mathrm{R}$ & SD & $X$ & $\mathrm{R}$ & SD \\
\hline AnnualH & 4 & $(2-7)$ & 3 & 6 & $(3-8)$ & 2 & 6 & $(3-9)$ & 3 & 4 & $(3-5)$ & 1 \\
\hline PerennH & 27 & $(24-31)$ & 4 & 26 & $(21-32)$ & 4 & 23 & $(17-31)$ & 6 & 12 & $(11-12)$ & 1 \\
\hline Shrubs & 8 & $(6-10)$ & 2 & 9 & $(5-13)$ & 3 & 6 & $(5-9)$ & 2 & 6 & $(3-7)$ & 2 \\
\hline Trees & 4 & $(3-6)$ & 2 & 4 & $(3-5)$ & 1 & 5 & $(0-7)$ & 3 & 2 & $(1-3)$ & 1 \\
\hline Ferns & 0 & $(0-1)$ & 1 & 1 & $(0-1)$ & 1 & 1 & $(0-1)$ & 1 & 0 & $(0-0)$ & 0 \\
\hline Hydroph & 7 & $(5-10)$ & 3 & 7 & $(5-8)$ & 1 & 6 & $(3-8)$ & 2 & 2 & $(2-2)$ & 0 \\
\hline Natives & 39 & $(24-47)$ & 7 & 40 & $(27-47)$ & 7 & 31 & $(19-43)$ & 10 & 15 & $(14-16)$ & 1 \\
\hline Exotics & 5 & $(3-8)$ & 3 & 5 & $(4-6)$ & 1 & 9 & $(6-11)$ & 2 & 8 & $(6-10)$ & 2 \\
\hline Richness & 44 & $(38-55)$ & 10 & 46 & $(33-52)$ & 7 & 40 & $(25-54)$ & 12 & 23 & $(21-25)$ & 2 \\
\hline P.AnnualH & 7.7 & $(5.1-12.7)$ & 4.3 & 12 & $(9.1-18.6)$ & 3.6 & 14.2 & $(9.1-18.9)$ & 4.4 & 18.8 & $(12.5-23.8)$ & 5.8 \\
\hline P.PerennH & 63 & $(56.4-71.1)$ & 7.5 & 58 & $(50.0-63.6)$ & 5.2 & 57.9 & $(52.3-68.0)$ & 7 & 50.3 & $(45.8-57.1)$ & 6 \\
\hline P.Shrubs & 19 & $(15.8-23.1)$ & 3.7 & 20 & $(15.2-25.0)$ & 3.9 & 16.3 & $(11.1-20.5)$ & 4.7 & 23.8 & $(14.3-29.2)$ & 8.3 \\
\hline P.Trees & 9.7 & $(7-9-10.9)$ & 1.6 & 9 & $(5.8-12.1)$ & 2.6 & 10.6 & $(0-15.9)$ & 7.2 & 7.1 & $(4.0-12.5)$ & 4.7 \\
\hline P.Ferns & 0.6 & $(0.0-1.8)$ & 1 & 1 & $(0.0-2.2)$ & 1.1 & 1 & $(0.0-2.3)$ & 1.2 & 0 & $(0.0-0.0)$ & 0 \\
\hline P.Hydroph & 16.5 & $(12.8-18.4)$ & 3.2 & 14.7 & $(9.6-21.2)$ & 4.1 & 13.6 & $(11.4-16.2)$ & 2.3 & 8.6 & $(8.0-9.5)$ & 0.8 \\
\hline P.Natives & 88.2 & $(85.5-92.1)$ & 3.5 & 87.9 & $(81.8-91.3)$ & 3.5 & 76.5 & (73.0-79.6) & 2.8 & 64.6 & $(58.3-71.4)$ & 6.6 \\
\hline P.Exotics & 11.8 & $(7.9-14.5)$ & 3.5 & 12.1 & $(8.7-18.2)$ & 3.5 & 23.5 & (20.4-27.0) & 2.8 & 35.4 & $(28.6-41.7)$ & 6.6 \\
\hline
\end{tabular}

* According to Júcar River Basin Authority.

flow regime, using data from the gauging station at Lorcha (located at site 6) to illustrate the change in the hydrological pattern before and after regulation Fig. 2).

The hydrological regime for sites 1 to 8 was characterised using average monthly flow data available from the same gauging station for the period 1999-2006. The discharge, drainage area and the two main water abstractions were used to estimate the discharge at the ungauged sites downstream of the Lorcha gauging station following the guidelines of Caissie \& El-Jabi (1995) and Caissie (2006). Seven hydrological variables were obtained in each river segment: the minimum (Fmin), mean (Fmean) and maximum flow (Fmax), 10 ${ }^{\text {th }}$ and $95^{\text {th }}$ percentiles (Fper10 and Fper95, respectively), standard deviation $(\mathrm{Fsd})$ and coefficient of variation $(\mathrm{Fcv})$ of the mean monthly flows (Table 2).

The mean (Dmean) and maximum river depth (Dmax) were estimated at 3 points along 5 transects at equal distances, while water surface width (Wwid) was estimated from the average of

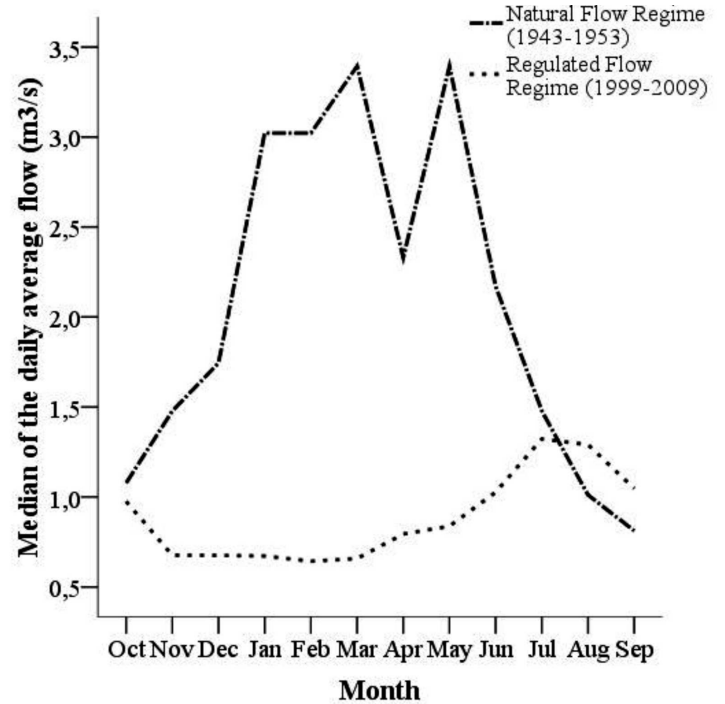

Figure 2. Medians of the mean daily flow by months, calculated at the gauging station at Lorcha (downstream of the Beniarrés dam) under natural conditions (1943-1953) and after dam construction (1999-2009) for the Serpis River, East Spain. Medianas del caudal medio diario por meses, calculado en la estación de aforo de Lorcha (aguas abajo del embalse de Beniarrés) bajo condiciones naturales (1943-1953) y tras la construcción de la presa (1999-2009) para el río Serpis, España. 
the 5 transects. Nine substrate types were considered in the margins and floodplain (R: bedrock, BB: big boulders, B: boulders, CB: cobbles, GR: gravel, FG: fine gravel, SA: sand, SI: silt and CL: clay) following a simplified classification of the American Geophysical Union (Martínez-Capel, 2000), and their percentage surface coverage was estimated visually. The percentage area associated with different water surface patterns was estimated using 4 classes: NoFlow, Flow1 (slow flow, mainly pools), Flow2 (medium, currents and glides) and Flow3 (fast, runs and riffles). Other variables recorded were the stability of the river bed and shading. Stability, i.e., the percentage of riverbed areas with a different mobility, was divided into 4 classes: Stab1-solid/hard (mainly bedrock and big boulders, an increase in the flow does not cause obvious erosion), Stab2stable (mainly gravel and cobbles, substrate little disturbed by an increase in the flow), Stab3instable (fine gravel and sand, particles easily transported by an increase in flow) and Stab4-soft (areas covered with silt). Shading was estimated as the percentage cover of different shade types over the channel in 3 classes: NoShade, Shade1moderate and Shade2-dense $(>70 \%)$.

Two indices were used to determine the spatial variation of the hydromorphological status of the river and its banks: QBR and IHF. The riparian habitat quality index (QBR; Munné et al., 2003) evaluates four components or subindices: total riparian vegetation cover (QBR1), vegetation cover structure (QBR2), vegetation cover quality (QBR3) and river channel alterations (QBR4). Two additional components of this index were considered: total geomorphological score (Stype) and geomorphological type of riparian habitat (Tgeo). According to Munné et al. (2003), the geomorphological score establishes three types of riparian habitats depending on the form and slope of the riparian environment and the presence of islands and hard substrata. Type 1 is related to closed riparian habitats (typical of headwaters), type 2 to midland riparian habitats (large gallery forests, middle reaches) and type 3 to large riparian habitats (lower courses). The total QBR score is the sum of the scores for the 4 items and varies between 0 and 100 points, clas- sifying riparian quality into class $\mathrm{I}(\mathrm{QBR} \geq 95)$, of excellent quality; class II $(90>$ QBR $>75)$, of good quality; class III (70 > QBR $>55)$, of moderate quality (beginning of important alteration); class IV (50 > QBR > 30), of poor quality (important alteration); and class $\mathrm{V}(\mathrm{QBR} \leq 25)$, of bad quality (extreme degradation).

The river habitat index (IHF; Pardo et al., 2004) is the sum of 7 subindices, coded as follows: riffle embeddedness or sedimentation in pools (IHF1), riffle frequency (IHF2), substrate composition (IHF3), flow velocity/depth regime (IHF4), shading of stream bed (IHF5), elements of heterogeneity (IHF6), e.g., roots, leaves and wood, and aquatic vegetation cover (IHF7). The total IHF score fluctuates between 0 and 100 points and is not classified into categories; a higher value indicates greater habitat diversity. However, IHF scores need to be adapted to each river typology because habitat heterogeneity may vary with river type. In general, a habitat with an IHF below 40 is considered to be affecting the associated biological communities (Prat et al., 2009). In this study, the IHF was classified into three classes: I (IHF > 60), good habitat quality; II (IHF 40-60), moderate quality, indicating that the habitat is sensitive to degradation; and III (IHF < 40), bad quality, indicating that the habitat is impoverished and can limit the presence of certain species, following previous studies of Mediterranean rivers (Vila-Escalé et al., 2005).

\section{Human impacts and pressures}

Finally, six variables related to human impacts and pressures were assessed at the sites using a ranking of magnitude. These variables were considered as absent when they were not identified at the site; as present when they were identified at one or a few points of the site, but scattered around the area; and as extensive when they were identified throughout the entire site or at multiple points. The variables assessed following these criteria were the presence of rigid lateral structures along margins (Struct), such as channelization, embankments or lateral protections, edifications in the floodplain (Urban), rubbish and rubble (Rubble), the influence of weirs (Weir- 
inf) and land use at margins (Agric-agricultural and Vfor-forest vegetation).

\section{Variable classification}

Prior to the statistical analyses, all of the variables were classified into predictor and response variables. The predictor variables were the subindices Stype and Tgeo (these are geomorphological variables not related to pressures) and the geographical (Elev, SlopeReach, SlopeArea and Area) and hydrological variables (Fmin, Fmean, Fmax, Fper10, Fper95, Fsd and Fcv). All of the human pressure indicator variables were also considered as predictor variables, i.e., DistWeir, DistRese, Struct, Urban, Rubble, Weirinf, Agric and Vfor. The response variables were the floristic composition, biotic variables (from the flora dataset), instream habitat characteristics (Dmean, Dmax, Wwid, substrate types, water surface patterns, riverbed stability and shading) and the total scores of the QBR and IHF indices and their subindices (except for Tgeo and Stype).

\section{Data analyses}

To meet objective A, a hierarchical cluster analysis and non-metric multidimensional scaling (NMDS) were performed using the PC-ORD v.4 statistical package (McCune \& Mefford, 1999). The cluster analysis allowed the grouping of study sites according to their similarity in floristic composition. Bray-Curtis distance along with group average was used as a linkage method. The cluster tree was cut off to find a balance between the number of groups and their internal homogeneity, thus obtaining a level of aggregation appropriate for our objectives. All of the species surveyed during the field campaign remained in the flora matrix. Although deleting rare species is recommended when extracting patterns with multivariate analysis, it is not appropriate to analyse species richness or to examine patterns in species diversity. No transformations were applied to the data matrix.

NMDS gives a multidimensional result. The number of iterations (small steps for adjusting the position of the $n$ entities or sites in the ordination space) to obtain the minimum stress value was 35. Stress is a measure of departure from monotonicity in the relationship between the dissimilarity (distance) in the original $p$-dimensional space (number of attributes) and the distance in the reduced $k$-dimensional ordination space (axes). According to McCune \& Grace (2002), most ecological community datasets have solutions with a stress between 10 and 20, and values in the lower half of this range are quite satisfactory. The stress patterns in the data were analysed to select the number of appropriate dimensions for the final ordination. Then, the final dimensionality was selected by inspecting the stress value associated with new axes on the ordination (only one in this case). A Monte Carlo test of significance was included. NMDS allows correlation of variables in a second matrix with the ordination scores (McCune \& Grace, 2002). In this study, NMDS was used as the base to relate the floristic matrix with the matrix of the biotic variables (calculated from the flora database) and QBR subindices (all of which were response variables). The distance used was Bray-Curtis.

The same procedure was carried out to meet objective B; i.e., cluster analysis and NMDS were performed to identify the relationships between instream habitat characteristics and IHF subindices. In this case, the response variables considered for the clustering and the main matrix of NMDS were Dmean, Dmax, Wwid, substrate types, water surface patterns, riverbed stability and shading. The minimum stress value was obtained after 40 iterations, indicating a reliable ordination with just one dimension. Before the analyses, data were transformed to make units of different attributes comparable. Thus, the data matrix was transformed so that data in percentages (range 0-100) were in the range of 01. Then, an arcsine square root transformation was applied to these variables, and finally, a general relativisation by variable was applied to all of the variables, including those that were not in percentage format. The cluster analysis allowed grouping of study sites according to their similarity in instream habitat characteristics. Euclidean distances along with group average as a linkage method were used in this case. The same trans- 


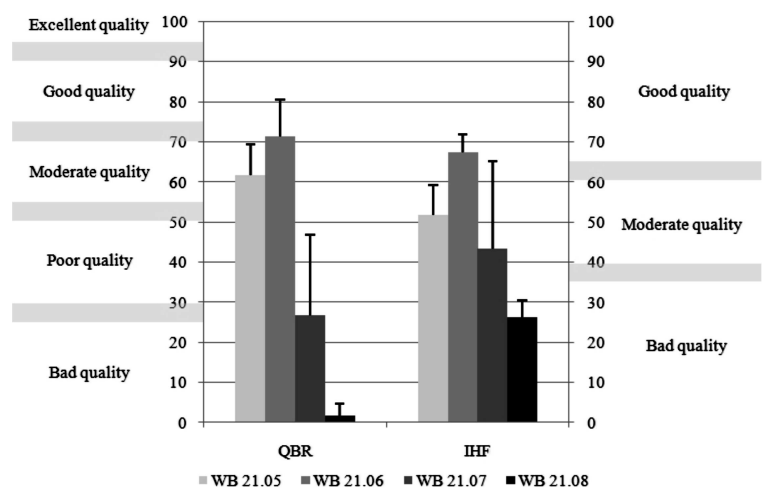

Figure 3. QBR and IHF mean values and standard error for the 4 water bodies studied in the Serpis River, East Spain. The quality ranges associated with each index are also indicated. Valor medio y error estándar de los índices QBR e IHF para las 4 masas de agua estudiadas en el río Serpis. También se indican los rangos de calidad asociados a cada índice.

formed main matrix was used in NMDS, and the final ordination was correlated with a second matrix composed of the IHF subindices.

Graphical and testing methods were used to explore the classification strength (Van Sickle, 1997) based on dissimilarity with the tool EnvClass (Snelder et al., 2009) in the statistical package R (R Development Core Team, 2008). The results are shown in a dendrogram of dissimilarity for the floristic and habitat groups. The vertical line (trunk) indicates the mean of all betweengroup dissimilarities $(\overline{\mathrm{B}})$. The length of the horizontal lines (branches of the dendrogram) represents the between-group dissimilarity $(\bar{B})$ minus the within-group dissimilarity $(\overline{\mathrm{W}} \mathrm{i})$, i.e., $\overline{\mathrm{B}}-\overline{\mathrm{W}} \mathrm{i}$. The larger the value of $\overline{\mathrm{B}}-\overline{\mathrm{W}} \mathrm{i}$ for the length of a branch to the left side, the more homogeneous the group is in relation to the whole dataset. The classification strength was evaluated with the indicator $\mathrm{CS}(\mathrm{CS}=\overline{\mathrm{B}}-\overline{\mathrm{W}})$. According to Van Sickle \& Hughes (2000), CS values can range from 0 , implying equal dissimilarity within and between classes (i.e., no class structure: $\overline{\mathrm{W}}=\overline{\mathrm{B}}$ ), to 1 , implying no dissimilarity within classes (i.e., $\overline{\mathrm{W}}=0$ ) and maximum dissimilarity between classes (i.e., $\overline{\mathrm{B}}=1$ ).

Two canonical correspondence analyses (CCA) were carried out with the statistical package $\mathrm{R}$ to meet objective $\mathrm{C}$; i.e., the first was performed to determine the main factors controlling the riparian floristic composition and quality and the second to determine the main factors controlling instream habitat characteristics and quality. Due to the large number of predictor variables in comparison with the number of study sites (16), a pre-selection was carried out using Spearman rank correlations to discriminate between relevant $(r>|0.7|, p<0.05)$, irrelevant and redundant variables. This analysis was performed using SPSS v.16 (SPSS Inc., 2007). A pre-selection of the response variables was also performed, and those that were irrelevant or redundant were not included in the CCA to avoid overlapping and make the plot clearer for interpretation. Nevertheless, the redundant variables were taken into consideration in the interpretation of the environmental gradients observed in the CCA plots.

\section{RESULTS}

The QBR and IHF indices described a similar longitudinal trend along the river (Fig. 3). None of the 16 study sites was qualified as excellent by QBR; three of them were good (sites 5, 6, 9); seven had moderate quality $(1,2,3,4,7,8,10)$; two were poor $(11,12)$; and four had bad quality $(13,14,15,16)$. Thus, $18.8 \%$ of the study sites were considered to be well conserved, $43.8 \%$ acceptably conserved and the remaining $37.5 \%$ badly conserved. For the IHF index, $50 \%$ of the study sites presented good quality (sites 4, 5, 6, $7,8,9,10,11), 25 \%$ moderate $(1,2,3,12)$ and $25 \%$ bad quality $(13,14,15,16)$. The longitudinal trend of the IHF values along the river was not as remarkable as that observed for QBR (Fig. 3). With respect to individual water bodies, the first and second water bodies downstream of the dam exhibited moderate and good quality, respectively, for both indices, while the third had poor riparian quality and moderate habitat quality, and the fourth presented bad quality in both indices.

\section{Floristic composition and riparian habitat quality}

A total of 117 vascular plant species were identified at the 16 sites; 22 of the species $(18.8 \%)$ 
were not native to the region. At sites 15 and 16 , only $58 \%$ and $64 \%$ of the species were native, respectively. Sites 3 and 5 showed the opposite trend, with only 8 and $9 \%$ exotic species being found, respectively. A negative correlation was identified between P.Natives and DistRese $(r=-0.829, p<0.001)$; this correlation was also valid for Elev and Area (both correlated with DistRese).

The cluster dendrogram was trimmed at the level of 3 groups for the flora dataset (Fig. 4A). This level of grouping provided a good compromise between loss of information (about $31 \%$ retained) and interpretability of the floristic similarities among sites. Two large branches were apparent in both dendrograms (flora and instream habitat), with one gathering the vast majority of the sites with bad riparian and habitat quality (mainly, sites in WB 21.08), while the remaining sites were included in the other branch. Regarding the similarities of the observed floristic patterns (Fig. 4A), sites 6 and 7 (in WB 21.06) were the most similar. Group 1 was formed by sites14 , group 2 by sites $5-11$ and group 3 by sites 12-16. It was especially noticeable that groups were formed by consecutive sites, which suggests that the changes in floristic composition were gradual along the river.

The final stress for the NMDS analysis of flora data was 11.88 , indicating a reliable ordination of sites according to their floristic composition (McCune \& Mefford, 1999). NMDS indicated a gradient in the species composition (plot not shown in this article) and revealed the same pattern in the ordination of sites as in the cluster: the sites were ordered from those with good riparian habitat quality, located below the dam and in the gorge, to those with bad quality, near the river mouth, at the other side of the ordination. One dimension alone explained $89.9 \%$ of the variability in the flora dataset.

The riparian species that were dominant at the extreme of this gradient associated with sites with good riparian quality were the following: Rorippa
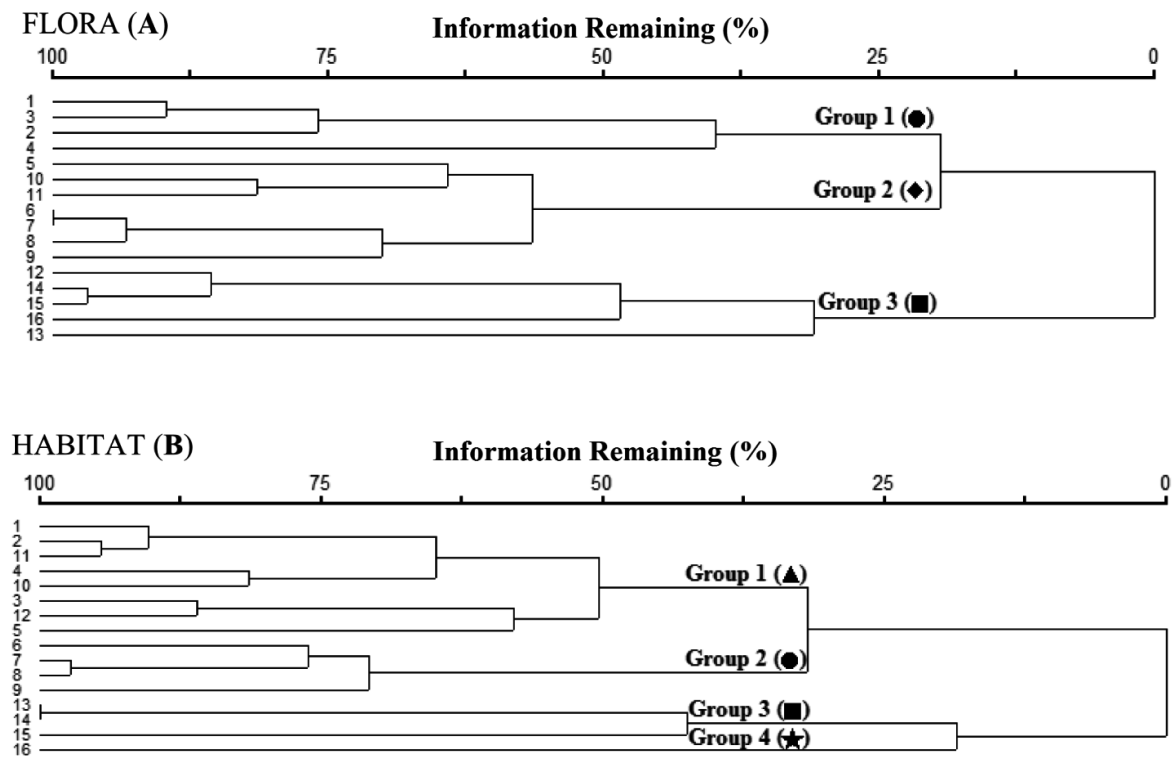

Figure 4. A) Hierarchical cluster dendrogram based on floristic composition (group average clustering with Bray-Curtis distance). B) Hierarchical cluster dendrogram based on instream habitat characteristics (group average clustering with Euclidean distance). In both dendrograms, the numbers on the left correspond to study sites. Selected groups of sites are also indicated. A) Dendrograma resultado del cluster jerárquico basado en la composición florística (agrupamiento promedio con distancia Bray-Curtis). B) Dendrograma resultado del cluster jerárquico basado en las características del hábitat fluvial (agrupamiento promedio con distancia Euclídea). En ambos dendrogramas, los números a la izquierda corresponden a los puntos de muestreo. También se indican los grupos de puntos de muestreo seleccionados. 
nasturtium-aquaticum (-0.601), Nerium oleander (-0.609), Scrophularia valentina (-0.666), Samolus valerandi (-0.672), Salix atrocinerea (-0.699), Apium nodiflorum (-0.702), Dorycnium rectum (-0.715), Potamogeton pectinatus $(-0.737)$ and Smilax aspera $(-0.823)$. To the other extreme (i.e., in the direction of bad riparian quality), these species were: Parietaria judaica (0.619), Ricinus communis (0.629), Arundo donax (0.664), Verbena officinalis (0.671), Calystegia sepium (0.707), Paspalum distichum (0.778) and Xanthium echinatum (0.893). Generally speaking, the first species mentioned are natives and the last are exotics. In addition, the strongest Pearson correlations among the first dimension of NMDS (representing floristic pattern) and the biotic variables corresponded to P.Exotics (0.857), PerennH (-0.891), Hydroph $(-0.828)$, Richness $(-0.763)$, Natives $(-0.828)$,
P.Natives (-0.857), QBR (-0.811) and QBR3 $(-0.822)$. The other QBR subindices were not strongly correlated with the floristic composition.

The classification strength was 0.24 , indicating that classification of the sites into 3 groups was appropriate (Van Sickle \& Hughes, 2000) because they were compact and homogeneous (Fig. 5A). In general terms, the first group (sites 1-4) was characterised by a high diversity of Natives, in particular Hydroph and PerennH; in the second group (sites 5-11), Trees and Ferns showed greater abundance than at other sites and a high diversity of Natives; the third group (sites 12-16) presented higher values for P.Exotics and AnnualH. Regarding riparian habitat quality, the first group exhibited QBR values in the range of 55-70 (median 62.5; SD 6.5), the second group between 45-85 (median 70; SD 13.5) and the third group between 0-30 (median 5; SD 12.5).
FLORA (A)

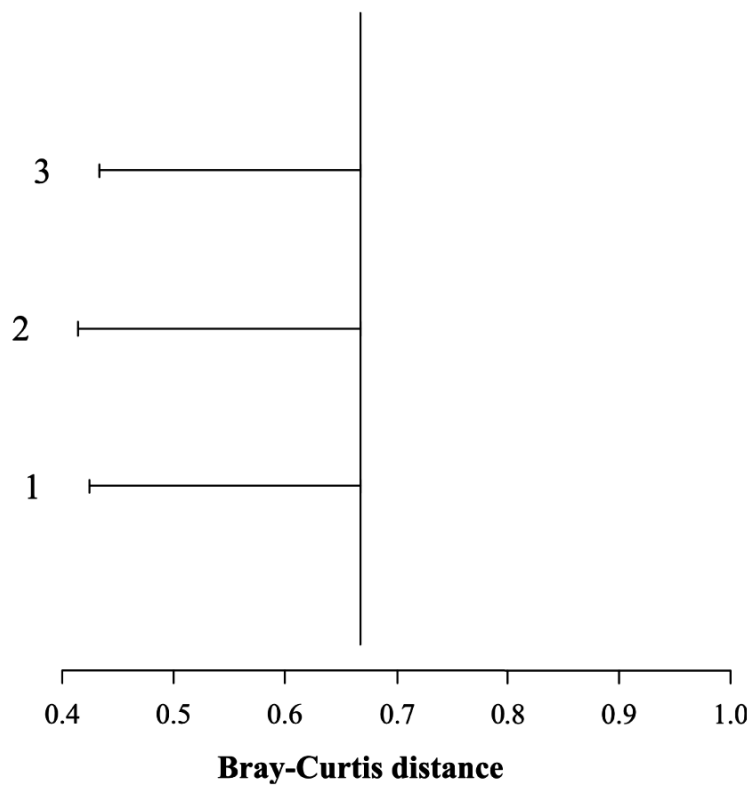

HABITAT (B)

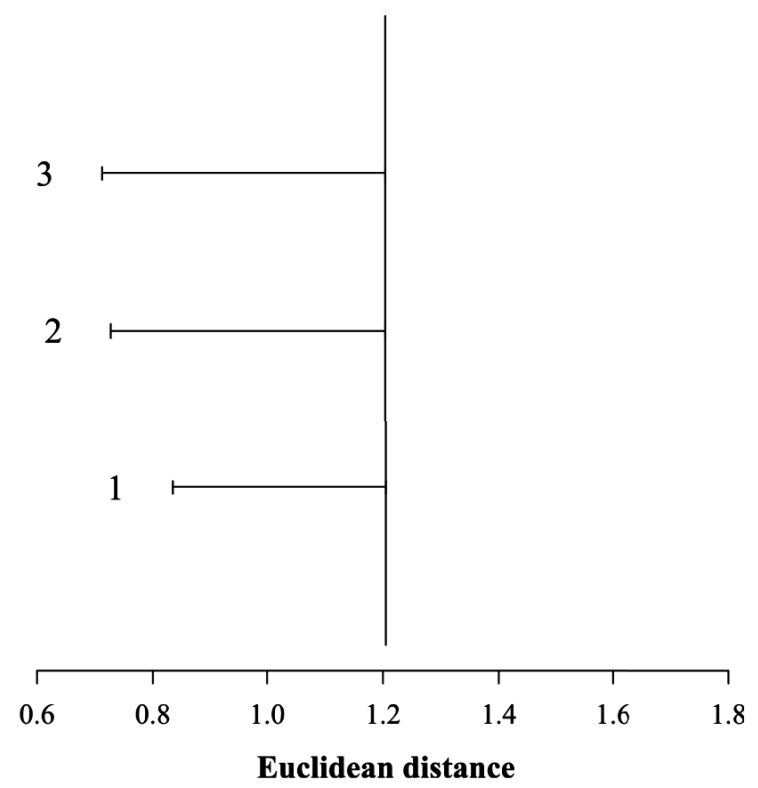

Figure 5. Dendrograms of the groups identified in the cluster analysis based on the floristic composition of the riparian habitats $(5 \mathrm{~A})$ and instream habitat characteristics $(5 \mathrm{~B})$ at the 16 study sites of the Serpis River, East Spain. The mean inter-group dissimilarity is indicated at the foot of the vertical line (trunk); the difference between the inter-group dissimilarity and within-group mean dissimilarity ( $\mathrm{Wi}$, end of the branch) is represented by the length of the horizontal line (branches). Dendrograma de los grupos identificados en el análisis cluster, basado en la composición florística (5A) y características del hábitat (5B) en los 16 puntos de mиestreo del río Serpis, España. La disimilaridad media inter-grupo está marcada al pie de la línea vertical (tronco); la diferencia entre la disimilaridad media inter-grupo y la disimilaridad media dentro de cada grupo (Wi, extremo de la rama) está representada por la longitud de cada línea horizontal (ramas). 


\section{Instream habitat characteristics and fluvial habitat heterogeneity}

Four groups were defined based on similarities in instream habitat characteristics (Fig. 4B), retaining $42.5 \%$ of the information. Sites 13 and 14 were the most similar, corresponding to the last site in WB 21.07 (hydrologically altered WB) and the first in WB 21.08 (hydrologically and morphologically altered WB). Group 1 was formed by sites $1-5$ and $10-12$, group 2 by sites $6-9$, group 3 by sites $13-15$ and group 4 only by site 16 , which was identified as clearly different than other sites. Only two of the groups ( 3 and 4 ) were formed by consecutive sites.

The final stress for the NMDS analysis of instream habitat characteristics data was 11.52 , indicating a reliable ordination of sites according to their instream habitat characteristics (McCune $\&$ Mefford, 1999; McCune \& Grace, 2002). One dimension was obtained as the best solution, representing $89.6 \%$ of the variance. The sites were distributed in the space defined by the habitat characteristics with a similar distribution to that revealed by the cluster tree. As with the flora data, there was a clear separation between groups of sites with different instream habitat quality.

The habitat characteristics most correlated with the first dimension, which best defined the extremes of the gradient, were in the following order (toward the sites with good instream habitat quality): Shade1 (-0.697), Shade2 (-0.703), B (-0.705), Flow3 (-0.795), Dmax (-0.822), Dmean $(-0.846)$ and Flow2 $(-0.858)$. To the other extreme, the variables were CL (0.758), SI (0.763), NoShade (0.786) and NoFlow (0.875). This quality gradient described by the habitat characteristics was strongly correlated with the total IHF value $(-0.896)$ and the subindices IHF1 $(-0.856)$, IHF2 $(-0.838)$ and IHF4 (-0.755). The other IHF subindices were not strongly correlated with the instream habitat characteristics.

The classification strength was 0.42 , indicating that classification of the sites into 4 groups was appropriate (Van Sickle \& Hughes, 2000) because the groups were compact and homogeneous (Fig. 5B). The fourth group does not appear in the dendrogram because it was comprised of only one site. The first group included sites immediately downstream of the dam (sites 1-5) and those just below the gorge (sites 10-12); they were characterised by a wide water surface (high values of Wwid), slow flow pattern (Flow1), substrate dominated by CB and GR, stable riverbed (Stab2) and moderate shading (Shade1). The second group (sites 6-9) corresponded to the sites located in the gorge, which were characterised by more shading (Shade2), greater water depths (Dmean and Dmax), harder substrates (R, BB and $\mathrm{B}$ ) and dominance of medium and fast flow patterns (Flow2 and Flow3). The third group (sites 13-15) incorporated the sites closer to the river mouth, with finer substrates (predominance of FG, SA and SI) and an absence of shading (NoShade). Finally, the fourth group (site 16) was characterised by even finer substrates (SA, SI and CL), soft river stability (Stab4) and an absence of shading and water flow (NoFlow). Regarding instream habitat quality, the first group presented IHF values between 45-64 (median 61.5; SD 8.4), the second group between 65-76 (median 68.5 ; SD 5.1), the third group between 20 25 (median 23; SD 2.5) and the fourth group was characterised by a value of 31 .

For both flora and instream habitat, it was not possible to test for differences among groups in relation to the biotic variables or QBR and IHF subindices, respectively, because the sampling size in the groups was smaller than 5 sites in some cases, which is the minimum, for instance, to carry out a non-parametric Kruskal-Wallis test.

\section{Variable reduction}

The number of predictor variables (geographical, hydrological, geomorphological and human pressures) was reduced from 21 to 12 based on the non-parametric correlations. Elev, DistRese and Area were considered redundant $(r=1$, $p<0.000$ ), and Area was selected for the CCA because this variable showed a stronger correlation with the axis CCA1. Moreover, a perfect correlation was found $(r=1, p<0.0001)$ between Fmax and Fsd; thus, only Fmax was included in the CCA. Fmax and Fper95 presented a moderate correlation $(r=0.731, p<0.01)$ but both of 
them showed a strong correlation with the axis CCA1. Due to their similar meaning, only Fmax was retained for the CCA. A high correlation existed between Fper10 and Fmin $(r=0.944$, $p<0.0001)$. In this case, only Fper10 was considered because its correlation with other variables achieved a higher level of significance in some cases. SlopeArea was considered irrelevant because it showed no strong correlation with any other variable. It only showed significant, but not strong correlations with DistWeir $(r=-0.676$, $p<0.01)$ and Agric $(r=0.530, p<0.05)$. The reason for this is that the sites where the watershed mean gradient was higher corresponded to the gorge, where weirs are more abundant, and similarly, where this gradient was lower, it corresponded to flatter areas, which are more suitable for agricultural use. The human pressures Weirinf and Agric were also considered to be irrelevant because they were not related to other variables. Fmean was considered irrelevant because of its lack of strength in the CCA and due to presenting no correlation with other riparian or instream habitat variables. It was only correlated with Area and other hydrological variables; however, it showed significant but not strong correlations with QBR3 $(r=0.639, p,<0.01)$ and Exotics $(r=-0.649, p<0.01)$. Finally, the most relevant predictor variables considered in both CCA plots were Area, SlopeReach and DistWeir (geographical), Fper10, Fmax and Fcv (hydrological), Tgeo and Stype (geomorphological) and Vfor, Struct, Rubble and Urban (human pressures).

Although there was no restriction on the number of response variables that could be shown in the CCA, those considered to be irrelevant (appearing overlapped in the centre of the plot, $r<0.1$ for the first two axes) or redundant (overlapped with others) were not included. The variables rejected were QBR1, QBR2 and QBR4 (irrelevant, not related to floristic composition), Ferns and P.Ferns (not correlated with others), PerennH, Shrubs, P.Natives, P.Hydroph and Richness (low correlation with the first two axes). Trees and P.Trees appeared overlapped. Only Trees was retained because it was correlated with more variables. The variables rejected in the CCA for the instream habitat character- istics were IHF3, IHF5, IHF6 and IHF7 (irrelevant, did not appear to be correlated with instream habitat characteristics in NMDS and actually showed a weak correlation with the first two CCA axes). Dmean and Dmax appeared overlapped because they exhibited a similar performance and similar correlation with CCA1. Only Dmean was retained for the analysis.

\section{Factors controlling riparian habitat quality}

The first two axes of the CCA for biotic variables and riparian habitat quality explained $83 \%$ (79 \%-axis1 and $5 \%$-axis2; Fig. 6A) of the cumulative variance in the response variables. The predictor variables (geographical, hydrological, geomorphological and human pressures) explained $90 \%$ of the riparian habitat characteristics with the first two axes. Axis 2 represented a small proportion of the data variability and did not show an interpretable pattern. The variables positively related to axis 1 were Struct (0.97), Fmax (0.91), Area (0.89), Fcv (0.82) and Rubble (0.76), while Vfor $(-0.80)$ and Fper10 $(-0.73)$ were negatively related. The QBR subindices were located opposite to the human pressures. No predictor variables had strong loadings on the second axis. Among the response variables, the strongest was P.Exotics (0.72). The positioning of variables and sites on the CCA plot showed a strong quality gradient, especially represented by axis 1, which divided the study sites into 2 groups (Fig. 6B). The most altered sites (belonging to cluster group 3 ) were found on the right side of the ordination, and those with good and moderate quality were located on the left side (cluster groups 1 and 2).

\section{Factors controlling instream habitat quality}

The first two axes of the CCA explained $60 \%$ (44\%-axis 1 and $16 \%$-axis2; Fig. 7A) of the cumulative variance in the response variables. The predictor variables explained $67 \%$ of the instream habitat characteristics and quality in the first two axes. Not all of the predictor (constrain- 

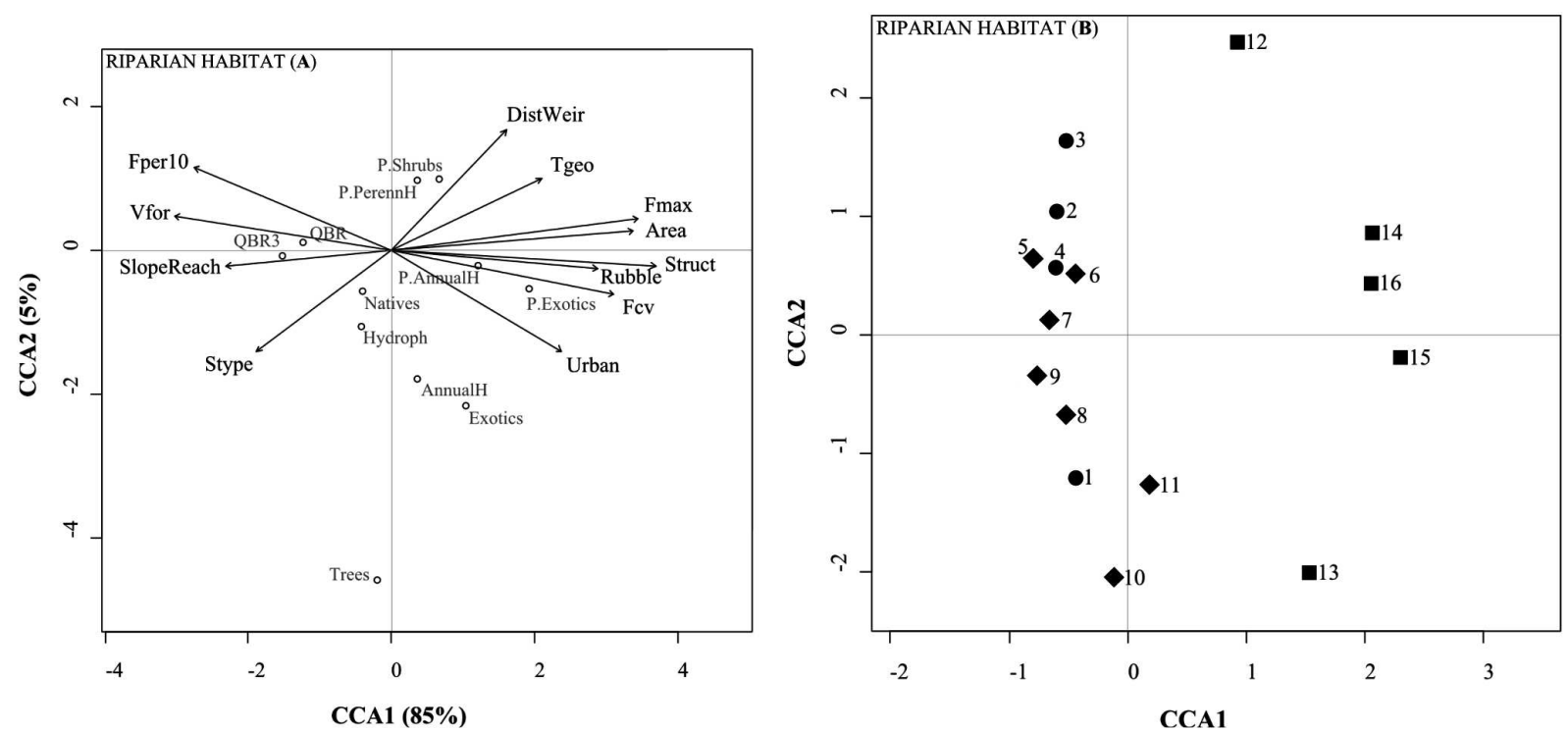

Figure 6. CCA ordination diagram showing the distribution of the biotic variables and QBR subindices (6A, left plot, in grey colour) and study site positions (6B, right plot) in relation to predictor variables (geographical, hydrogeomorphological and indicators of human pressures, with arrows in black) in the space represented by the first two axes, which explain $90 \%$ of the data variability. The length of the arrows indicates the strength of the variable in that dimensionality of the solution, and they point in the direction of the gradient. For brevity, the codes for the variables are indicated in the text. Only those with loadings $>|0.70|$ have been considered for interpretation. The symbols in 6B indicate a cluster's group membership. Diagrama de ordenación del CCA mostrando la distribución de las variables bióticas y subíndices del QBR (6A, gráfico izquierdo, en color gris) y la posición de los puntos de muestreo (6B, gráfico derecho) en relación con las variables predictoras (geográficas, hidrogeomorfológicas e indicadoras de presiones antrópicas, con flechas en negro) en el espacio representado por los dos primeros ejes, los cuales explican el $90 \%$ de la variabilidad total. La longitud de las flechas indica la fuerza de la variable en esa dimensión de la solución y marca la dirección del gradiente. Por brevedad, los códigos de las variables están indicados en el texto. Sólo aquellas con pesos $>|0.70|$ han sido consideradas para la interpretación. Los símbolos en $6 B$ indican la pertenencia de los puntos de muestreo a los grupos procedentes del cluster.

ing) variables contributed in the same way; the vast majority of them showed a stronger ordination in the first axis than in the second. The only positively related variable was Vfor (0.73), whereas the negatively related variables were Struct (-0.93), Fmax (-0.89), Area $(-0.84)$ and Fcv $(-0.71)$. No predictor variables gave strong loadings on the second axis. Among the response variables, those that were more positively related to the first axis were BB (0.92), Shade2 (0.79) and Flow3 (0.74); whereas those that were more negatively related were CL (-2.02), Stab4 $(-1.58)$, NoFlow $(-1.39)$, NoShade $(-1.16)$ and SI (-1.08). The only variable positively related to the second axis was Flow1 (0.92), and those negatively related were BB $(-1.04)$ and Stab1 $(-0.88)$. The IHF subindices were located opposite to the human pressures. The study sites showed a clear distribution in the CCA (Fig. 7B); those that were more altered and with lower habitat quality were located on the bottom left (cluster groups 3 and 4, in Fig. 4B), whereas those with good and moderate quality were found on the right side of the ordination. The sites in cluster 1 were in the positive region of the second axis, and the sites belonging to the cluster 2 were located in the negative region.

\section{DISCUSSION}

\section{Riparian and instream habitat quality downstream of the Beniarrés dam}

In the present study, we were interested in the gradual changes in riparian flora and certain instream habitat characteristics in a hydromorphologically altered river ecosystem; these 

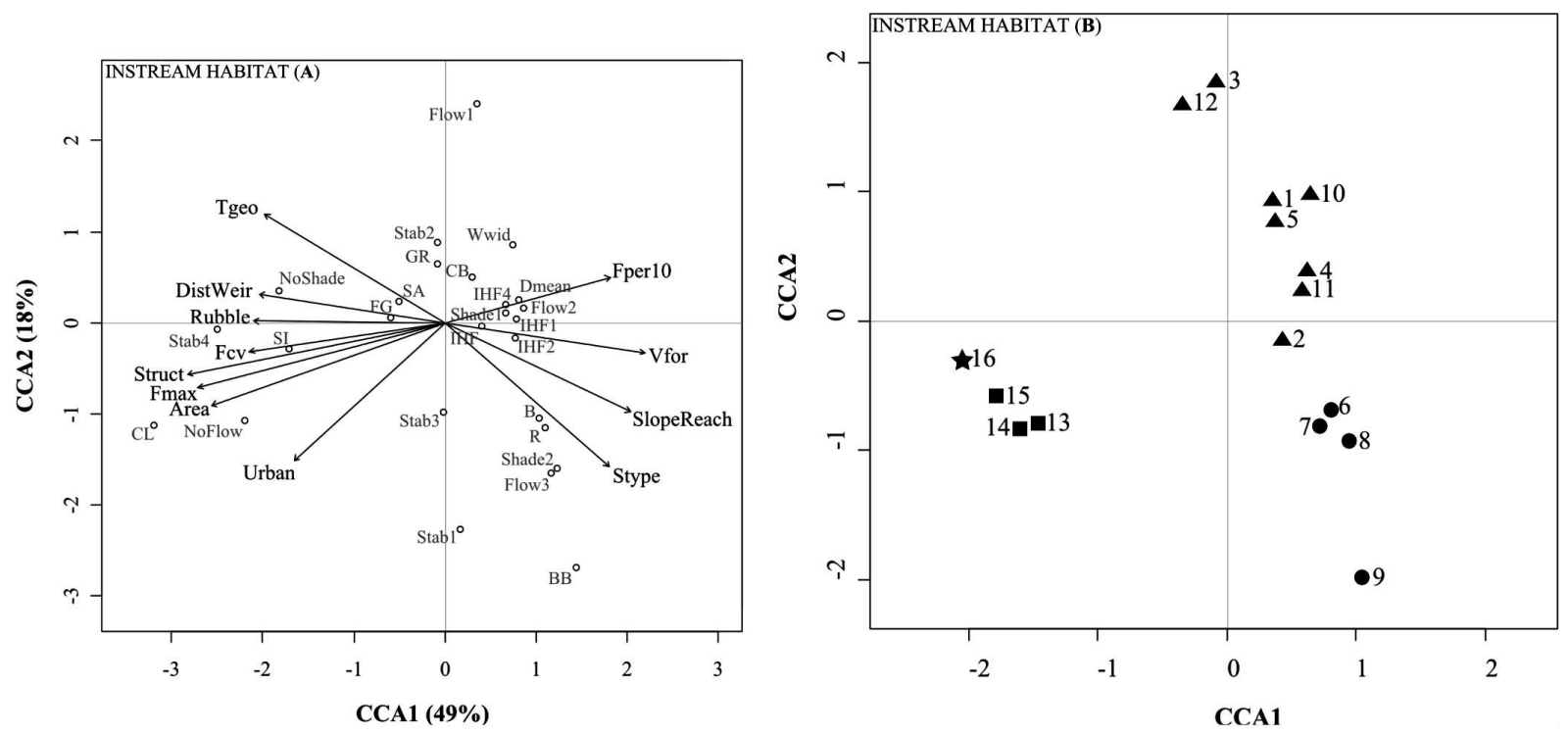

Figure 7. CCA ordination diagram showing the distribution of instream habitat characteristics and the IHF subindices (7A, left plot, in grey colour) and study site positions (7B, right plot) in relation to predictor variables (geographical, hydrogeomorphological and indicators of human pressures, with arrows in black) in the space represented by the two first axes, which explain $67 \%$ of the data variability. The length of the arrows indicates the strength of the variable in that dimensionality of the solution, and they point in the direction of the gradient. For brevity, the codes for the variables are indicated in the text. Only those with loadings $>|0.70|$ have been considered for interpretation. The symbols in 7B indicate a cluster's group membership. Diagrama de ordenación del CCA mostrando la distribución de las características del hábitat fluvial y subíndices del IHF (7A, gráfico izquierdo, en color gris) y la posición de los puntos de muestreo (7B, gráfico derecho) en relación con las variables predictoras (geográficas, hidrogeomorfológicas e indicadoras de presiones antrópicas, con flechas en negro) en el espacio representado por los dos primeros ejes, los cuales explican el $67 \%$ de la variabilidad total. La longitud de las flechas indica la fuerza de la variable en esa dimensión de la solución y marca la dirección del gradiente. Por brevedad, los códigos de las variables están indicados en el texto. Sólo aquellas con pesos $>|0.70|$ han sido consideradas para la interpretación. Los símbolos en $7 B$ indican la pertenencia de los puntos de muestreo a los grupos procedentes del cluster.

changes were also related to the QBR and IHF indices, which are the indices most widely used by Spanish water administrations (Aguilella et al., 2005; ACA, 2006). Our results provided a clear picture of the hydromorphological conditions in consecutive segments downstream of a large dam. It was possible to distinguish a gradient in the riparian and instream habitat quality, clearly defining the extremes formed by two groups of sites: those with good and moderate quality (below the dam and in the middle course) and those in the lower course, where the degradation of the river and its banks was more notable, and the riparian and habitat quality were lowest. More specifically, a wider and more laterally active channel characterised the sites located in the first WB, with little variability in the flow regime and no periods of null flow and where the vegetation was diverse and natural. The surrounding area was a mosaic of farmlands and natural forests. The sites in the second WB showed less influence of regulation and were hydromorphologically constrained by the characteristics of the gorge (higher slope, harder substrate and more stable riverbed). There were no significant human pressures associated with this water body and there was a connection among aquatic-riparian-terrestrial vegetation, which was a relevant characteristic for obtaining a high riparian quality. Despite the hydrological alteration of this area, the increase in quality could be explained by its low accessibility and the low level of intervention in the surrounding area. Other studies in Mediterranean rivers (Suárez et al., 2002) have determined that sites with better structured ri- 
parian forests are located in inaccessible stretches, generally localised in gorges and in headwaters (Palma et al., 2009).

The third WB was located at the transition between the gorge and the coastal plain. The river becomes wider again in this region, and there was space for well-developed riparian forests. Because the sediment became finer in this area, the floodplain was more prone to agricultural use. Finally, sites within the fourth WB, which was entirely located in the plain, presented higher flows in the wet season (higher Fmax) but were also associated with periods when the channel was completely dry (NoFlow). A lack of water during part of the year disrupted the fluvial connectivity in this area and made some aquatic habitats unsuitable for the fish fauna. This water body suffered the pressures of water abstractions more intensely than the other water bodies and in addition, the morphological degradation (associated with the presence of lateral structures and urban uses in the floodplain) was also more intense. These alterations have resulted in reduction of riparian and habitat quality and impoverishment of vegetation (with a stronger presence of annual herbs and exotic species being observed). Recent studies in Catalonian Mediterranean rivers have emphasised that excessive water abstraction impairs their capacity to support native biota (Benejam et al., 2010), as can happen at these sites near the river mouth.

\section{Longitudinal variation of the floristic composition and hydromorphological indices}

The total QBR score and the vegetation cover quality (QBR3) were the elements most correlated with the floristic composition. It makes sense that QBR3 was the most strongly correlated sub-index because it evaluates factors such as the diversity of native trees and shrubs, the presence of exotic species and riparian continuity along the river corridor, taking into account the geomorphological river type during the scoring. The highest riparian quality was found at those sites associated with less intervention in the surrounding area (predominately Vfor) and a higher slope in the river and in the riparian environment (Tgeo 1-closed and 2-midland). The other subindices, which refer to the percentage of vegetation cover (QBR1), structure (QBR2) and river channel alterations (QBR4), were not strongly correlated with the floristic composition; in the study area, the variability of these subindices and their relationship with habitat degradation was not relevant, but in other rivers, they could play an important role. In this Mediterranean river, natural processes may be limiting the development of a climax riparian forest as well as the structure and cover; therefore, the QBR score could be underestimating the conservation status of the study area because it is not possible to reach high values. Thus, it would be advisable to compare the deviation of the values to a geomorphological reference (Suárez et al., 2002) or to apply the modified QBR (Costa, 2006) defined for rivers in more arid conditions, which introduces modifications in the scoring of the subindices from the original version from Munné et al. (1998).

Regarding IHF, the most significant correlations with instream habitat characteristics were the total IHF score, riffle embeddedness or sedimentation in pools (IHF1), riffle frequency (IHF2) and the flow velocity/depth regime (IHF4). The other subindices showed a low correlation, but the characteristics they referred to were important along the gradient described; e.g., the substrate type (implicit in IHF3) or shading (IHF5) clearly reproduced the gradient, corresponding at one extreme to sites with a hard substrate and dense shading and at the other extreme to sites with a finer substrate and without shading.

The changes in the instream habitat among the 16 sites were more prominent than the changes in the floristic composition, which varied gradually along the river (CS values). This can be explained because the river flows through different geomorphological environments, and the gorge is a hydrogeomorphological and floristic discontinuity that induces greater diversity in the study area. According to Braatne et al. (2008), geomorphic transitions are naturally associated with ecological changes. However, the river is classified as the same ecotype throughout all of this area. This suggests that it would be advisable to reclassify the gorge into a different ecotype because regular inventories could confound these natu- 
rally higher scores with recovery from hydrological alteration or other pressures. Similarly, the thresholds applicable to the quality classes for the indices could be different than those applied in the reaches upstream or downstream of the gorge. Other studies (Braatne et al., 2008) have concluded that habitat heterogeneity is very different between river types, and in some cases, larger differences have been found than among reference and non-reference sites within a river typology (Barquín et al., 2011).

We suggest that instead of using fixed characterisations of some indices, it could be useful to employ an open characterisation for certain riparian attributes and then measure the deviation of those riparian attributes from the geomorphological reference condition. This system would be simpler to apply and could be more transferable across regions in comparison with the large variety of indices currently developed in Europe and in the Iberian Peninsula. One basic variable that should be included in such assessments is the presence and extension of recruitment in a site (not included in the QBR). This is one of the main functions affected by the management of large dams (Auble et al., 1997; Mahoney \& Rood, 1998) and has recently been included in some indices, such as RQI (González del Tánago et al., 2006; González del Tánago \& García de Jalón, 2011) and RFV (Magdaleno et al., 2010). Another weakness identified in QBR is related to the percentage of cover in the riparian area, as it is evaluated with a higher score when the percentage of cover increases. However, below a dam, the cover increases in many cases as a consequence of flood regulation and vegetation encroachment, rather than because of improvement of ecological status; therefore, this variable is not always related to the natural status of a riparian zone (Rood \& Mahoney, 1995; Wilcock et al., 1996).

\section{Factors controlling riparian and instream habitat quality}

Our results revealed the importance of maintaining at least a minimum flow during the year along the entire river length because the sites with lower (or even null) Fper10 values exhib- ited bad quality. These degraded sites also experienced the highest flow values (Fmax) because large flows are related to a larger watershed area, but this variable was not related to hydromorphological quality in this study. Apart from the extreme values, the flow variability deserves special attention. Observation of the flow regime before and after regulation indicated that flows have been reduced in both magnitude and variability. The hydrograph at Lorcha is now inverse and plain; i.e., the highest water levels appeared in the summer months and the lowest in winter. Additionally, the natural fluctuation during the year has disappeared. Alteration of typical variability in natural flows due to dams has also been observed in other Mediterranean-type rivers of eastern (Vidal-Abarca et al., 2002) and central Spain (Baeza et al., 2003). A general reduction of flows due to dam operation has important consequences because it disconnects riparian zones from riverine influence (Magilligan et $a l ., 2003)$. However, the natural autumnal floods downstream of the dam were extremely large in some years, with contributions from unregulated tributaries in the lower basin. Therefore, the high values of variability in this area are a consequence of the large differences between artificial low flow periods (due to water regulation and abstraction) and natural floods that are not retained in the reservoir. In unregulated Mediterranean rivers, flow regimes are naturally highly variable (Gasith \& Resh, 1999), but in the case of the Serpis River, this variability is a consequence of dam regulation and natural events.

Another important issue is the occurrence of large floods, which have triggered channelization of the river course (Segura \& Carmona, 1999), especially in the lowest region of the Serpis River. Thus, the presence of lateral structures (Struct) has been established as one of the main pressures affecting the riparian and habitat quality in this area. The low quality in the lower course was also related to the presence of urban uses because many of these structures were planned for urban protection. The high correlations found between Fmax and NoFlow and with the presence of rigid lateral structures in the channel (Struct) seem to be the reasons for the increase in the presence of exotic species at the low- 
est sites. According to Tabacchi et al. (1998) and Naiman et al. (2005), colonisation of the lower parts of rivers by exotic species is a major consequence of the interaction between natural (hydrological) and human-induced disturbances. In general terms, the stronger the anthropogenic impact on the land, the more successful the dispersion and encroachment of exotic species (Lodge, 1993; Poff et al., 1997). This finding is of note for the Serpis River, where not only the flow regulation, but its synergy with other human pressures near the river mouth has dramatically affected the riparian plant communities and the hydromorphological quality in the area. Similarly, other studies (e.g., Wang et al., 1997) have concluded that urban land use is more harmful to biotic communities than agricultural land use along margins. In the Serpis River, the pressure exerted by agricultural use (Agric) was not clear, although it was expected to play a role in the riparian and instream habitat quality. Forested land use (Vfor) affected river quality in a positive manner and was plotted very close to the indices.

Several measures to improve river quality can be derived from this study, such as the implementation of environmental flows designed with a more natural pattern, and with the aim of providing periodic high-flows events and maintaining minimum flows during irrigation periods. This study highlights the importance of reducing the human-induced periods of null flows and of recovering natural flow variability for improvement of hydromorphological quality. Another measure that should be considered would be to provide the river with more space and lateral mobility by removing some lateral structures (in places where flood risk prevention allows this measure) and incorporating abandoned agricultural plots into its banks.

From a general perspective, our results indicate the importance of science-based monitoring of river networks to meet the requirements of the Water Framework Directive, considering river geomorphology as a valuable feature. If this is not done, using the current system of ecotypes alone can lead to invalid comparisons among river segments with their reference sites. Certain geomorphological features can be more determinant of river quality than the mean flow or water- shed area and should be considered in the evaluation and potential restoration of Iberian rivers.

\section{ACKNOWLEDGMENTS}

The authors would like to thank the reviewers for their comments and suggestions on an earlier version of this manuscript and the Júcar River Basin Authority (CHJ) for supplying public hydrological data. This study was supported by the Spanish Ministry of Environment and Rural and Marine Affairs (RIBERA Project) and the Ministry of Education and Science (projects TETIS-2, CGL2005-06219; POTECOL, CGL2007-66412; RIPFLOW, CGL2008-03076-E/BTE). We would also like to thank the CEIC Alfons El Vell (Gandia) for partially funding this research with a grant to Virginia Garófano Gómez. The translation of this paper was funded by the Universitat Politècnica de València, Spain.

\section{REFERENCES}

ACA-AGÈNCIA CATALANA DE L'AIGUA. 2006. HIDRI-Protocolo para la valoración de la calidad hidromorfológica de los ríos. $59 \mathrm{pp}$.

ACA-AGÈNCIA CATALANA DE L'AIGUA. 2008. La gestió i recuperació de la vegetació de ribera. Guia tècnica per a actuacions en riberes. Departament de Medi Ambient i Habitatge. Generalitat de Catalunya. 176 pp.

AGUILELLA, A., J. RIERA, M. GÓMEZ-SERRANO, O. MAYORAL \& E. MOREYRA. 2005. Evaluación del estado ecológico de los ríos de la cuenca hidrográfica del Júcar mediante el uso del indice $Q B R$. Memoria final. Trabajo realizado por el Jardí Botànic de la Universitat de València para la Confederación Hidrográfica del Júcar. Valencia. $258 \mathrm{pp}$.

AUBLE, G. T., M. L. SCOTT, J. M. FRIEDMAN, J. BACK \& V. J. LEE. 1997. Constraints on establishment of plains cottonwood in an urban riparian preserve. Wetlands, 17: 138-148.

BAEZA SANZ, D., F. MARTÍNEZ-CAPEL \& D. GARCÍA DE JALÓN. 2003. Variabilidad temporal de caudales: aplicación a la gestión de ríos regulados. Ingeniería del Agua, 10(4): 469-478. 
BARQUÍN, J., D. FERNÁNDEZ, M. ALVÁREZCABRIA \& F. PEÑAS. 2011. Riparian quality and habitat heterogeneity assessment in Cantabrian rivers. Limnetica, 30(2): 329-346.

BENEJAM, L., P. L. ANGERMEIER, A. MUNNÉ \& E. GARCÍA-BERTHOU. 2010. Assessing effects of water abstraction on fish assemblages in Mediterranean streams. Freshwater Biology, 55: 628642.

BLONDEL, J. \& J. ARONSON. 1999. Biology and wildlife of the Mediterranean region. Oxford University Press, Oxford. 328 pp.

BRAATNE, J. H., S. B. ROOD, L. A. GOATER \& C. L. BLAIR. 2008. Analyzing the impacts of dams on riparian ecosystems: a review of research strategies and their relevance to the Snake River through Hells Canyon. Environmental Assessment, 41: 267-281.

BRIERLEY, G. J. \& K. A. FRYIRS. 2005. Geomorphology and river management: applications of the River Styles Framework. Blackwell. Oxford. $398 \mathrm{pp}$.

BURCH, G. J., R. K. BATH, I. D. MOORE \& E. M. O'LOUGHLINA. 1987. Comparative hydrological behaviour of forested and cleared catchments in southeastern Australia. Journal of Hydrology, 90 (1-2): 19-42.

CAISSIE, D. 2006. River discharge and channel width relationships for New Brunswick rivers. Canadian Technical Report of Fisheries and Aquatic Sciences, 2637. 26 pp.

CAISSIE, D. 1995. Comparison and regionalization of hydrologically based instream flow techniques in Atlantic Canada. Canadian Journal of Civil Engineering, 22: 235-246.

CHARLTON, R. 2008. Fundamentals of fluvial geomorphology. Routledge. New York. 234 pp.

CEDEX-CENTRO DE ESTUDIOS Y EXPERIMENTACIÓN DE OBRAS HIDRÁULICAS. 2004. Directiva 2000/60/CE. Caracterización de los tipos de ríos y lagos. Versión 1.0. Ministerio de Fomento. Madrid. 95 pp.

CHJ-CONFEDERACIÓN HIDROGRÁFICA DEL JÚCAR. 2005. Informe para la Comisión Europea sobre los artículos 5 y 6 de la Directiva Marco del Agua. Demarcación Hidrográfica del Júcar. Ministerio de Medio Ambiente. Valencia. 528 pp.

CHJ-CONFEDERACIÓN HIDROGRÁFICA DEL JÚCAR. 2007. Anexos del Plan Especial de alerta y eventual sequía en la Confederación Hidrográfica del Júcar. Ministerio de Medio Ambiente. Valencia. 202 pp.

CHJ-CONFEDERACIÓN HIDROGRÁFICA DEL JÚCAR. 2009. Documento técnico de referencia. Identificación y delimitación de masas de agua superficial y subterránea. Ámbito territorial de la Confederación Hidrográfica del Júcar. Ministerio de Medio Ambiente. Valencia. 100 pp.

COSTA, J. C. 2006. Plan Director de Riberas de Andalucía. Conserjería de Medio Ambiente. Junta de Andalucía. 310 pp.

EUROPEAN COMMISSION. 2000. Directive 2000/ 60/EC of the European Parliament of the council of 23 October 2000 establishing a framework for Community action in the field of water policy. $O f$ ficial Journal of the European Communities L327: $1-72$.

FERNÁNDEZ GONZÁLEZ, D., J. BARQUÍN ORTIZ \& P. J. RAVEN. 2011. A review of habitat assessment methods for rivers; indices vs. characterization protocols. Limnetica, 30(2): 217-234.

GARÓFANO-GÓMEZ, V., F. MARTÍNEZ-CAPEL \& R. DELGADO ARTÉS. 2009. Les riberes del Serpis. Gestió de l'aigua per a la seua conservació. CEIC Alfons El Vell. Gandia. Valencia. $206 \mathrm{pp}$.

GARDE, R. J. 2006. River morphology. New Age International. $479 \mathrm{pp}$.

GASITH, A. \& V. H. RESH. 1999. Streams in Mediterranean climate regions: abiotic influences and biotic responses to predictable seasonal events. Annual Review of Ecology and Systematics, 30: 5181.

GONZÁLEZ DEL TÁNAGO, M., D. GARCÍA DE JALÓN, F. LARA \& R. GARILLETI. 2006. Índice RQI para la valoración de las riberas fluviales en el contexto de la Directiva Marco del Agua. Ingeniería Civil, 143: 97-108.

GONZÁLEZ DEL TÁNAGO, M., D. GARCÍA DE JALÓN. 2011. Riparian Quality Index (RQI): A methodology for characterizing and assessing environmental conditions of riparian zones. Limnetica, 30(2): 235-254.

GUTIÉRREZ, C., A. SALVAT \& F. SABATER. 2001. IVF Índex per a l'avaluació de la qualitat del medi fluvial a partir de la vegetació de ribera. Documents tècnics de l'Agència Catalana de l'Aigua. $49 \mathrm{pp}$.

KONDOLF, G. M. \& R. J. BATALLA. 2005. Hydrological effects of dams and water diversions on rivers of Mediterranean-climate regions: Examples 
from California. In: Catchment dynamics and river processes: Mediterranean and other climate regions. C. Garcia and R. J. Batalla (eds.): 197-211. Elsevier Publishers Limited. London.

LODGE, D. M. 1993. Biological invasions: Lessons for ecology. Trends in Ecology \& Evolution, 8: 133-137.

MAHONEY, J. M. \& S. B. ROOD. 1998. Streamflow requirements for cottonwood seedling recruitmentan interactive model. Wetlands, 18: 634-645.

MAGDALENO, F., R. MARTÍNEZ \& V. ROCH. 2010. Índice RFV para la valoración del estado del bosque de ribera. Ingeniería Civil, 157: 85-96.

MAGILLIGAN, F. J., K. H. NISLOW \& B. E. GRABER. 2003. Scale-independent assessment of discharge reduction and riparian disconnectivity following flow regulation by dams. Geology, 31: 569572.

MARTÍNEZ-CAPEL, F. 2000. Preferencias de microhabitat de Barbus bocagei, Chondrostoma polylepis y Leuciscus pyrenaicus en la cuenca del río Tajo. Tesis doctoral. Universidad Politécnica de Madrid. ETSI Montes, Madrid. 337 pp.

MCCUNE, B. \& M. J. MEFFORD. 1999. PC-ORD. Multivariate Analysis, Version 4. MjM Software Design, Gleneden Beach, Oregon, USA.

MCCUNE, B. \& J. B. GRACE. 2002. Analysis of Ecological Communities. MjM Software Design, Gleneden Beach, Oregon, USA. 300 pp.

MUELLER-DOMBOIS, D. \& H.ELLENBERG. 1974. Aims and methods of vegetation ecology. John Wiley and Sons, New York. 547 pp.

MUNNÉ, A., C. SOLÁ \& N. PRAT. 1998. QBR: Un índice rápido para la evaluación de la calidad de los ecosistemas de ribera. Tecnología del Agua, 175: 20-37.

MUNNÉ, A., N. PRAT, C. SOLÁ, N. BONADA \& M. RIERADEVALL. 2003. A simple field method for assessing the ecological quality of riparian habitat in rivers and streams: QBR index. Aquatic Conservation: Marine and Freshwater Ecosystems, 13: 147-163.

NAIMAN, R. J., H. DÉCAMPS \& M. E. MCCLAIN. 2005. Riparia-Ecology, Conservation and Management of Streamside Communities. Elsevier Acad. Pr., Amsterdam, 430 pp.

NAIMAN, R. J., J. J. LATTERELL, N. E. PETTIT \& J. D. OLDEN. 2008. Flow variability and the biophysical vitality of river systems. C. R. Geosciences, 340: 629-643.
OLLERO OJEDA, A., D. BALLARÍN FERRER, E. DÍAZ BEA, D. MORA MUR, M. SÁNCHEZ FABRE, V. ACÍN NAVERAC, M. T. ECHEVERRÍA ARNEDO, D. GRANADO GARCÍA, A. I. GONZÁLEZ DE MATAUCO, L. SÁNCHEZ GIL \& N. SÁNCHEZ GIL. 2008. IHG: Un índice para la valoración hidrogeomorfológica de sistemas fluviales. Limnetica, 27(1): 171-188.

OLLERO OJEDA, A., D. BALLARÍN FERRER \& D. MORA MUR. 2009. Aplicación del índice hidrogeomorfológico IHG en la cuenca del Ebro. Guía metodológica. Ministerio de Medio Ambiente y Medio Rural y Marino. Confederación Hidrográfica del Ebro. Zaragoza. 93 pp.

OLLERO OJEDA, A., A. IBISATE GONZÁLEZ DE MATAUCO, L. E. GONZALO PEÑA, V. ACÍN NAVERAC, D. BALLARÍN FERRER, E. DÍAZ BEA, S. DOMENECH ZUECO, M. GIMENO GUTIÉRREZ, D. GRANADO GARCÍA, J. H. GARCÍA, D. MORA MUR \& M. SÁNCHEZ FABRE. 2011. The IHG index for hydromorphological quality assessment of rivers and streams: updated version. Limnetica, 30(2): 255-262.

PALMA, A., R. FIGUEROA \& V. H. RUIZ. 2009. Evaluación de ribera y hábitat fluvial a través de los índices QBR e IHF. Gayana, 73(1): 57-63.

PARDO, I., M. ÁLVAREZ, J. CASAS, J. L. MORENO, S. VIVAS, N. BONADA, J. ALBA-TERCEDOR, P. JÁIMEZ-CUÉLLAR, G. MOYÀ, N. PRAT, S. ROBLES, M. L. SUÁREZ, M. TORO \& M. R. VIDAL-ABARCA. 2004. El hábitat de los ríos mediterráneos. Diseño de un índice de diversidad de hábitat. Limnetica, 21(3-4): 115-132.

PÉREZ, A. J. 1994. Atles climàtic de la Comunitat Valenciana (1961-1990). Conselleria d'Obres Publiques, Urbanisme i Transports de la Generalitat Valenciana. 205 pp.

POFF, N. L., J. D. ALLAN, M. B. BAIN, J. R. KARR, K. L. PRESTEGAARD, B. D. RICHTER, R. E. SPARKS \& J. C. STROMBERG. 1997. The natural flow regime: A paradigm for river conservation and management. BioScience, 47(11): 769-784.

PRAT, N., P. FORTUÑO \& M. RIERADEVALL. 2009. Manual d'utilització de L'Índex d'Hàbitat Fluvial (IHF). Diputació de Barcelona. 25 pp.

PRENDA, J., M. CLAVERO, F. BLANCO-GARRIDO, A. MENOR \& V. HERMOSO. 2006. Threats to the conservation of biotic integrity in Iberian fluvial ecosystems. Limnetica, 25: 377-388.

R DEVELOPMENT CORE TEAM. 2008. $R$ : A language and environment for statistical computing. 
R Foundation for Statistical Computing, Viena, Austria. ISBN 3-900051-07-0, URL http://www. R-project.org

ROOD, S. B. \& J. M. MAHONEY. 1995. River damming and riparian cottonwoods along the Marias River, Montana. Rivers, 5(3): 195-207.

SEGURA BELTRÁN, F. \& P. CARMONA GONZÁLEZ. 1999. Las inundaciones en la Plana de Gandía: formas y procesos. Cuadernos de Geografía, 65-66: 045-060.

SNELDER, T., A. LEHMANN, N. LAMOUROUX, J. LEATHWICK \& K. ALLENBACH. 2009. Strong influence of variable treatment on the performance of numerically defined ecological regions. Environmental Management, 44: 658-670.

SPSS Inc., an IBM Company. 2007. SPSS 16.0 Statistical software for windows. Chicago. Illinois.

SUÁREZ, M. L., M. R. VIDAL-ABARCA, M. M. SÁNCHEZ-MONTOYA, J. ALBA-TERCEDOR, M. ÁLVAREZ, J. AVILÉS, N. BONADA, J. CASAS，P. JÁIMEZ-CUÉLLAR，A. MUNNÉ, I. PARDO, N. PRAT, M. RIERADEVALL, M. J. SALINAS, M. TORO \& S. VIVAS. 2002. Las riberas de los ríos mediterráneos y su calidad: el uso del índice QBR. Limnetica, 21: 135-148.

TABACCHI, E., D. CORRELL, R. HAUER, G. PINAY, A. M. PLANTY-TABACCHI \& R. WISSMAR. 1998. Role of riparian vegetation in the landscape. Freshwater Biology, 40: 497-516.

US GOVERNMENT. 1977. The Clean Water Act. Public Law 95-217 (Dec. 27, 1977).

VANDER MAAREL, E. 1979. Transformation of cover-abundance values in phytosociology and its effects on community similarity. Vegetatio, 39(2): 97-114.

VAN SICKLE, J. 1997. Using mean similarity dendrograms to evaluate classifications. Journal of Agricultural, Biological and Environmental Statistics, 2: 370-388.
VAN SICKLE, J. \& R. HUGHES. 2000. Classification strengths of ecorregions, catchments and geographic cluster for aquatic vertebrates in Oregon. Journal of North American Benthological Society, 19 (3): 370-384.

VAN STEETER, M. M. \& J. PITLICK. 1998. Geomorphology and endangered fish habitats of the upper Colorado River 1. Historic changes in streamflow, sediment load and channel morphology. Water Resources Research, 34(2): 287-302.

VIDAL-ABARCA, M. R., M. L. SUÁREZ \& R. GÓMEZ. 2002. Caudales y aportaciones en la Cuenca del Segura: ¿Son significativos los datos hidrológicos? Actas del III Congreso Ibérico de Gestión y Planificación del Agua. Sevilla, España. 10 pp.

VILA-ESCALÉ, M., A. MUNNÉ, C. SOLÀ, M. RIERADEVALL, N. CID, J. MESTRE \& N. PRAT. 2005. El seguiment de l'estat ecològic del riu Foix des del 1997 al 2004. I Trobada d'Estudiosos del Foix. Diputació de Barcelona: 29-34.

VIÑALS, M. J., J. ORS \& E. A. MOLINER (dirs.). 2001. La Marjal de Gandia: estudi del medi físic $i$ humà. Gandia (Valencia). Ajuntament de Gandia, Departament de Medi Ambient. 170 pp.

WANG, L., J. LYONS, P. KANEHL \& R. GATTI. 1997. Influences of watershed land use on habitat quality and biotic integrity in Wisconsin streams. Fisheries, 22(6): 6-12.

WILDI, O. 2010. Data analysis in vegetation ecology. John Wiley \& Sons, Ltd. 211 pp.

WILCOCK, P. R., G. M. KONDOLF, W. V. MATTHEWS \& A. F. BARTA. 1996. Specification of sediment maintenance flows for a large gravelbed river. Water Resources Research, 32(9): 29112921.

WORLD COMMISSION ON DAMS. 2000. Dams and development. A new framework for decisionmaking. Report. Earthscan Publications Ltd., London and Sterling, VA. 404 pp. 